Document downloaded from:

http://hdl.handle.net/10251/72942

This paper must be cited as:

Ozuna López, C.; Puig Gómez, CA.; García Pérez, JV.; Mulet Pons, A.; Carcel Carrión, JA. (2013). Influence of high intensity ultrasound application on mass transport, microstructure and textural properties of pork meat (Longissimus dorsi) brined at different $\mathrm{NaCl}$ concentrations. Journal of Food Engineering. 119(1):84-93. doi:10.1016/j.foodeng.2031.05.016.

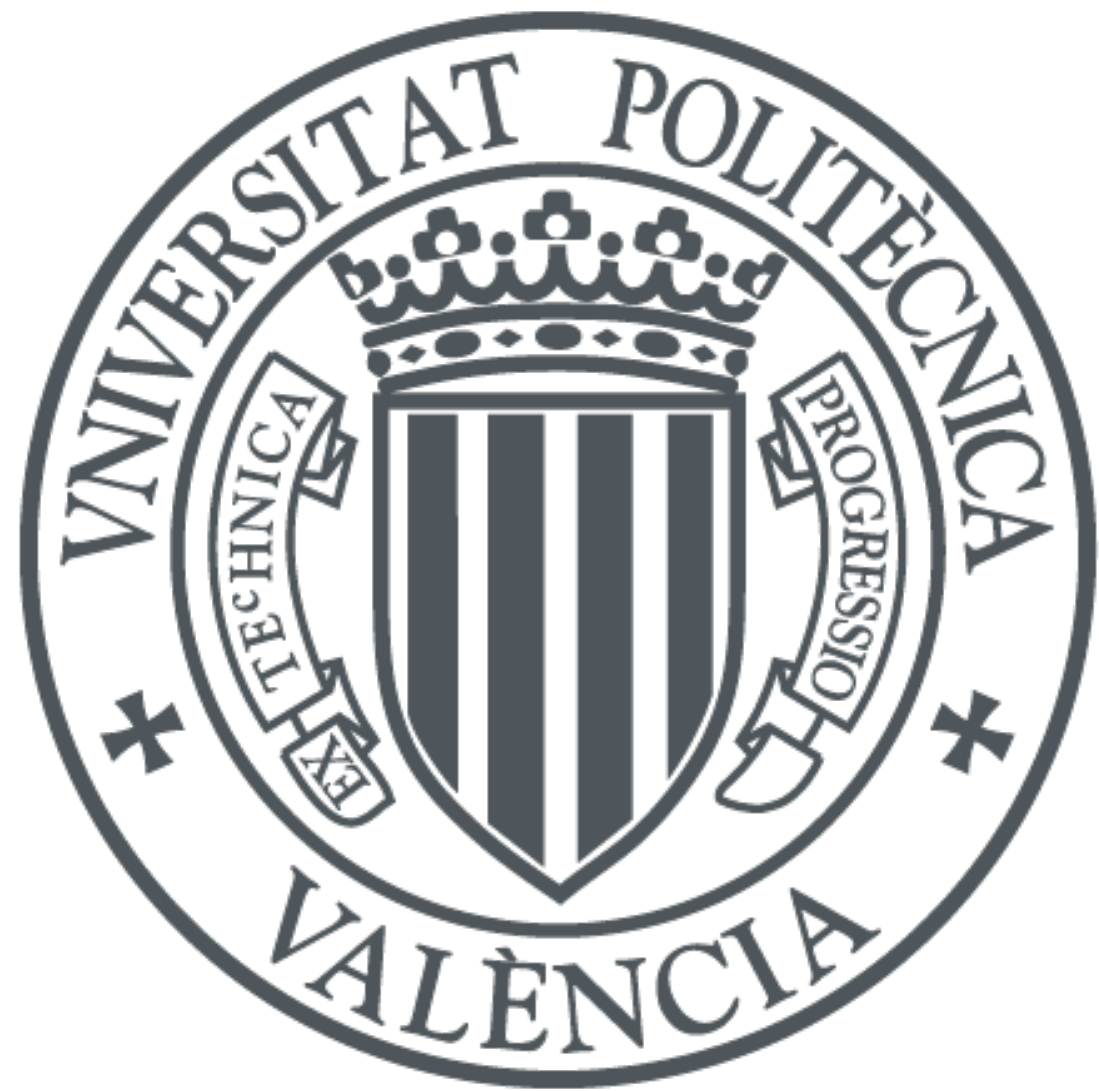

The final publication is available at

https://dx.doi.org/10.1016/j.jfoodeng.2013.05.016

Copyright Elsevier

Additional Information 
1 Influence of High Intensity Ultrasound Application on Mass Transport,

2 Microstructure and Textural Properties of Pork Meat (Longissimus dorsi)

Brined at Different $\mathrm{NaCl}$ Concentrations.

*Corresponding author.

Juan A. Cárcel.

Grupo de Análisis y Simulación de Procesos Agroalimentarios. Departamento de Tecnología de Alimentos. Universitat Politècnica de València.

Camino de Vera. s/n. E46022. Valencia, Spain

Tel.: +349638793 65; Fax: +34963879839

E-mail address: jcarcel@ tal.upv.es.

\section{Cárcel $^{\mathrm{a}, *}$}

${ }^{\text {a }}$ Grupo de Análisis y Simulación de Procesos Agroalimentarios. Departamento de Tecnología de Alimentos. Universitat Politècnica de València.

Camino de Vera. s/n. E46022. Valencia, Spain

${ }^{\mathrm{b}}$ Grupo de Microestructura y Química de Alimentos. Departamento de Tecnología de Alimentos. Universitat Politècnica de València.

Camino de Vera. s/n. E46022. Valencia, Spain 


\section{ABSTRACT}

The aim of this work was to evaluate the effect of high intensity ultrasound and $\mathrm{NaCl}$ concentration on the brining kinetics $\left(5 \pm 1{ }^{\circ} \mathrm{C}\right)$ of pork loin as well as its influence on the textural and microstructural changes. In order to identify the effect of both factors on $\mathrm{NaCl}$ and moisture transport, kinetics were analyzed by taking the diffusion theory into account. The textural and microstructural analysis of raw and brined meat both with and without ultrasound application was carried out. The experimental results showed that the brine $\mathrm{NaCl}$ concentration not only determined the final $\mathrm{NaCl}$ content in meat samples but also the direction of water transport. The $\mathrm{NaCl}$ and moisture effective diffusivities were improved by ultrasound application. The final $\mathrm{NaCl}$ and moisture content and the ultrasound application promoted changes in instrumentally measured meat texture, which were confirmed via microstructural observations.

Keywords: mass transfer, power ultrasound, modeling, diffusivity, texture, Cryo-SEM, SEM. 


\section{Introduction}

Over 1.2 million tons of meat products produced per year makes Spain the fourth most important country in the European Union in this regard, being the dry-cured products the most valuable ones in the Spanish meat industry (AICE, 2011). One of the main stages during the processing of dry-cured products is salting. Actually, this operation is mainly carried out by salting the meat pieces with solid salts $(\mathrm{NaCl})$, but it could also be performed by brining (Barat et al., 2006). Compared with other food processes, brining is a slow process and, for that reason, the food industry is searching for alternative technologies for improving the mass transfer kinetics (Rastogi et al., 2002), such as high intensity ultrasound application (Cárcel et al., 2007a).

In liquid medium, ultrasound induces cavitation (Leighton, 1998), temperature gradients within the material (Mason and Lorimer, 2002), mechanical phenomena, such as the "sponge effect", generation of microchannels and microstirring on interfaces (Muralidhara et al., 1985). These effects can not only increase the mass transport kinetics but also imply structural changes and, consequently, changes in textural properties. Thereby, textural changes induced by ultrasound have been observed in, among others, tomato juice (Vercet et al., 2002), yoghurt (Wu et al., 2000), bell peppers (Gabaldón-Leyva et al. 2007) or meat (Jayasooriya et al., 2007; Pohlman et al., 1997).

Meat has great biochemical and structural complexity. During meat brining, changes in $\mathrm{NaCl}$ and moisture content take place (Graiver et al., 2006), which extend meat's shelf life and modify organoleptic characteristics, such as juiciness, texture and flavor. Mass transfer driving forces between meat and brine are linked to chemical gradients and $\mathrm{NaCl}$-induced changes in the water holding capacity (WHC) of meat proteins (Shi and Le Maguer, 2002; Vestergaard et al., 2005). The $\mathrm{NaCl}$ concentration in brine affects the direction of moisture transport as well as the equilibrium state (Cheng and Sun, 2008). A low NaCl content in the 
meat increases the water holding capacity (WHC) (Nguyen et al., 2010), a phenomenon known as "salting-in" which is linked to the meat protein net charge modification. However, a high $\mathrm{NaCl}$ content in meat could also bring about a decrease in WHC, probably due to the insolubilization of proteins ("salting-out") (Graiver et al., 2009). Therefore, the $\mathrm{NaCl}$ concentration in the brine solution can not only affect the chemical gradients, but also the WHC, thus affecting the magnitude of mass transport.

Modeling is a fundamental tool to quantify the mass transport (Cárcel et al., 2007a), as well as to evaluate the effectiveness on that of new technologies, such as ultrasound. But in addition, modeling also provides relevant information to understand the changes undergone by foodstuffs during processing, which usefulness complements the information given by other techniques, such as textural and microstructural ones (Pérez-Munuera et al., 2008). Thereby, different electron microscopy techniques, Larrea et al. (2007) have been used to characterize the microstructure of Biceps femoris and Semimebranousus muscles during the processing of Teruel dry-cured ham. Ruiz-Ramírez et al. (2005) described the effect of $\mathrm{NaCl}$ and $\mathrm{pH}$ on the relationship between water content and textural parameters in dry-cured muscles.

The main aim of this work was to evaluate the influence of high intensity ultrasound application on the meat brining kinetics using different $\mathrm{NaCl}$ concentrations in the brine solution. Moreover, the ultrasonic effects in transport phenomena have been quantified by modeling and linked to the induced changes in microstructural and textural meat properties.

\section{Materials and methods}

2.1.Raw material and sample preparation

Fresh pork loins (Longissimus dorsi) were purchased at a local slaughterhouse (Valencia, Spain). The pieces selected had a pH of $5.3 \pm 0.30$, which was measured in-situ by means of a pH-meter (pH STAR, Matthäus, Germany) at three different points along the muscle avoiding 
fatty areas. Parallelepiped shaped samples (length $50 \mathrm{x}$ width $30 \mathrm{x}$ thickness $10 \mathrm{~mm}$ ) were obtained from the central part of loin pieces using a sharp knife. Before brining, samples were wrapped in plastic waterproof film and kept frozen at $-18 \pm 0.5{ }^{\circ} \mathrm{C}$ (maximum storage time 120 hours).

\subsection{Brining treatments}

Brining experiments with (US, $40 \mathrm{kHz} ; 37.5 \mathrm{~W} / \mathrm{dm}^{3}$ ) and without ultrasound application (CONTROL) were carried out using brine solutions of different $\mathrm{NaCl}$ concentrations $(50,100$, 150, 200, 240 and $\left.280 \mathrm{~kg} \mathrm{NaCl} / \mathrm{m}^{3}\right)$. The highest $\mathrm{NaCl}$ concentration used $\left(280 \mathrm{~kg} \mathrm{NaCl} / \mathrm{m}^{3}\right)$ involved brine saturation at $5 \pm 1{ }^{\circ} \mathrm{C}$, which was pointed to by the presence of $\mathrm{NaCl}$ crystals in the solution.

Brining treatments were carried out in an ultrasonic cleaning bath (4 L, Selecta, Spain) where the temperature was held at $5 \pm 1{ }^{\circ} \mathrm{C}$ by brine recirculation from a cooling reservoir. A peristaltic pump (302S Limited, Watson/Marlow, United Kingdom) drove the brine from the cooling reservoir equipped with a chiller (3000778, J.P. Selecta, Spain) and a mechanical stirrer (RZR 1, Heidolph Instruments, Germany).

Before each brining experiment, 6 meat samples were thawed at constant temperature $(2 \pm 1$ $\left.{ }^{\circ} \mathrm{C}\right)$ for 24 h. Then, the samples were blotted, weighed (PB3002-S/PH, J.P., Mettler Toledo, Spain) and their size was measured by using a Vernier caliper. Afterwards, they were placed in a hollow sample holder and simultaneously introduced in the brine. For a homogenous brining, the position of the meat samples was changed every $5 \mathrm{~min}$. In the US experiments, ultrasound was continuously applied. Samples were taken out of the brine at preset times (15, 30, 45, 60, 90 and 120 minutes) and immersed in distilled water for $20 \mathrm{~s}$ to remove any adhered surface brine. Finally, samples were blotted, wrapped in plastic waterproof film and frozen $\left(-18 \pm 0.5^{\circ} \mathrm{C}\right)$ until moisture and $\mathrm{NaCl}$ measurements were taken. 
122 at least.

$$
\mathrm{S}=\mathrm{S}_{\mathrm{eq}}+\left(\mathrm{S}_{0}-\mathrm{S}_{\mathrm{eq}}\right)\left[2 \sum_{\mathrm{n}=0}^{\infty} \frac{1}{\lambda_{\mathrm{n}}^{2} \mathrm{~L}^{2}} \mathrm{e}^{-\mathrm{D}_{\mathrm{S}} \lambda_{\mathrm{n}}^{2} \mathrm{t}}\right]
$$

136 Where $\lambda_{n}$ are the eigenvalues obtained from $\lambda_{n} L=(2 n+1) \frac{\pi}{2}$. The equilibrium moisture and

$137 \mathrm{NaCl}$ content values $\left(S_{e}, W_{e}\right)$ were determined by immersing meat samples in the different brine solutions for at least $48 \mathrm{~h}$. From previous experiments, this time was considered to be

After brining, moisture and $\mathrm{NaCl}$ content were measured from ground meat (at 300 r.p.m., Blixer® 2, Robot coupe, France). The moisture content was determined following AOAC standards (Method No. $950.46 \mathrm{AOAC}, 1997$ ). While in the case of $\mathrm{NaCl}$, the procedure A mathematical model based on Fick's $2^{\text {nd }}$ law was used to separately describe the evolution of moisture and $\mathrm{NaCl}$ content in the sample during brining (Cranck 1975). Samples were considered to become slab geometry bodies due to the fact that they were not nearly as thick $(10 \mathrm{~mm})$ as they were high $(50 \mathrm{~mm})$ and wide $(30 \mathrm{~mm})$, thus, mass transfer was simplified as a one-dimensional problem. Constant effective diffusivities $\left(D_{s}\right.$ and $\left.D_{w}\right)$, negligible changes in temperature and sample volume, solid symmetry, homogeneous $\mathrm{NaCl}$ and moisture initial content and negligible external resistance (Gou et al., 2003) were assumed during processing. Eqs. 1 and 2 show the solution of the diffusion model in terms of average moisture and $\mathrm{NaCl}$ content.

$\mathrm{W}=\mathrm{W}_{\mathrm{eq}}+\left(\mathrm{W}_{0}-\mathrm{W}_{\mathrm{eq}}\right)\left[2 \sum_{\mathrm{n}=0}^{\infty} \frac{1}{\lambda_{\mathrm{n}}^{2} \mathrm{~L}^{2}} \mathrm{e}^{-\mathrm{D}_{\mathrm{w}} \lambda_{\mathrm{n}}^{2} \mathrm{t}}\right]$ long enough to achieve the equilibrium. 
140 Both effective diffusivity values, $D_{s}$ and $D_{w}$, were identified by separately fitting Eqs. 1 and 2

141 to moisture and $\mathrm{NaCl}$ transport kinetics. The identification was performed by minimizing the 142 squared differences between the experimental and calculated average sample moisture and

$143 \mathrm{NaCl}$ content. For that purpose, the Generalized Reduced Gradient (GRG) optimization 144 method, available in the Microsoft Excel spreadsheet from Microsoft Office XP Professional, 145 was used.

2.4.Textural and microstructural analysis

148

149

150

151

152

153

154

155

Meat texture and microstructure were studied in raw material, US (40 kHz; $\left.37.5 \mathrm{~W} / \mathrm{dm}^{3}\right)$ and CONTROL brined samples for 120 minutes using low, intermediate and high $\mathrm{NaCl}$ concentrations (50, 200 and $280 \mathrm{~kg} \mathrm{NaCl} / \mathrm{m}^{3}$, respectively). Samples were brined in triplicate at least.

\subsubsection{Texture}

Hardness, characterized as maximum penetration force, was evaluated in brined samples using a Texture Analyzer (TAX-T2 ${ }^{\circledR}$, Stable Micro System, United Kingdom). Penetration tests were conducted with a $2 \mathrm{~mm}$ flat cylinder probe (SMS P/2N), a crosshead speed of 1 $\mathrm{mm} / \mathrm{s}$ and a strain of $60 \%$ (penetration distance $6 \mathrm{~mm}$ ). In each meat slice, penetration tests were carried out at 12 points at least.

\subsubsection{Cryo-scanning electron microscopy (Cryo-SEM)}

Cubic samples (side $3 \mathrm{~mm}$ ) of raw and brined meat were immersed in slush Nitrogen $(-210$ ${ }^{\circ} \mathrm{C}$ ), and quickly transferred to a cryo-trans (CT $15000 \mathrm{C}$, Oxford Instruments, England) linked to a scanning electron microscope (JSM-5410, Jeol, Japan). Samples were cryofractured at $-180{ }^{\circ} \mathrm{C}$, etched at $-90^{\circ} \mathrm{C}$ and gold-coated, allowing cross-section visualization. 
The microscopic observations were carried out at $10 \mathrm{kV}$, a working distance of $15 \mathrm{~mm}$ and a temperature below $-130{ }^{\circ} \mathrm{C}$.

2.4.3. Scanning electron microscopy (SEM) with combined dispersion X-ray analysis (SEM-EDX).

Cubic samples (side $3 \mathrm{~mm}$ ) from raw and brined meat were immersed in liquid $\mathrm{N}_{2}$ and then freeze-dried at $1 \mathrm{~Pa}$ for 3 days (LIOALFA-6, Telstar, Spain). The fixed samples were vacuum sealed in vials in the same freeze-drier so that they would remain stable (Llorca et al., 2001). The fixed samples were individually placed on SEM slides with the aid of colloidal silver and then gold-coated with (SCD005, Baltec, Germany) at $10^{-2} \mathrm{~Pa}$ and an ionization current of 40 mA. The samples were observed in a scanning electron microscope (JSM-5410, Jeol, Japan) equipped with an X-ray detector and LINK data-processing system (INCA 4.09, Oxford Instruments, England) at an acceleration voltage of $10-20 \mathrm{kV}$ which provides internal information about the standards of energy dispersive X-ray spectra of the elements analyzed $\left(\mathrm{Na}^{+}\right.$and $\left.\mathrm{Cl}^{-}\right)$. This technique is an analytical tool that allows the ions $\mathrm{Cl}^{-}$and $\mathrm{Na}^{+}$inside the samples to be identified (Grote and George, 1984). For EDX (energy-dispersive X-ray) analysis, samples were carbon-coated (CEA035, Baltec, Germany). Mapping images of $\mathrm{Cl}^{-}$ and $\mathrm{Na}^{+}$distribution in meat samples were made using a voltage of $20 \mathrm{kV}$ and at a working distance of $15 \mathrm{~mm}$.

\subsection{Fitting model evaluation and statistical analysis}

In order to evaluate the ability of the models to fit the experimental data, the percentage of explained variance (\%VAR) was computed (Eq. 3) (Cárcel et al., 2007a). Confidence intervals for the estimation of the effective diffusivities $\left(D_{s}\right.$ and $\left.D_{w}\right)$ were assessed in order to determine the reliability of the model prediction. 
$\% \mathrm{VAR}=\left[1-\frac{\mathrm{S}_{\mathrm{tw}}^{2}}{\mathrm{~S}_{\mathrm{w}}^{2}}\right] \times 100$

191 Where $S^{2}{ }_{w}$ and $S^{2}{ }_{t w}$ are the variance of the sample and the estimation, respectively.

192 Multifactor ANOVA and LSD (Least Significant Difference) intervals were estimated to

\section{Results and discussion}

3.1. $\mathrm{NaCl}$ and water transport

\subsection{1. $\mathrm{NaCl}$ and water content}

Fig. 1 shows the $\mathrm{NaCl}$ content of loin samples during brining, which is also considered the $\mathrm{NaCl}$ gain, due to the fact that the $\mathrm{NaCl}$ content in meat samples was negligible. $\mathrm{NaCl}$ concentration in the brine influenced significantly on $\mathrm{NaCl}$ content (Fig. 2A). Thus, when using a brine solution of $50 \mathrm{~kg} \mathrm{NaCl} / \mathrm{m}^{3}$, the $\mathrm{NaCl}$ content in the meat after $120 \mathrm{~min}$ of brining was almost four times lower than when using $280 \mathrm{~kg} \mathrm{NaCl} / \mathrm{m}^{3}$. The $\mathrm{NaCl}$ gain is mainly linked to osmotic mechanisms, thus the hydrodynamic flux increases as the pressure gradients between the meat and brine get higher (Schmidt et al., 2008). Other factors, such as temperature, $\mathrm{pH}$ and muscle microstructure, can also affect the $\mathrm{NaCl}$ gain (Barat et al., 2006). Ultrasound also significantly $(\mathrm{p}<0.05)$ influenced the $\mathrm{NaCl}$ gain (Fig. $2 \mathrm{~B}$ ); as an example, for a brining time of $90 \mathrm{~min}$ and using the highest $\mathrm{NaCl}$ concentration $\left(280 \mathrm{~kg} \mathrm{NaCl} / \mathrm{m}^{3}\right)$ (Fig. 1), the $\mathrm{NaCl}$ content in the CONTROL samples was $0.315 \pm 0.020 \mathrm{~kg} \mathrm{NaCl} / \mathrm{kg}$ initial d.m. while the content in US samples reached $0.359 \pm 0.033 \mathrm{~kg} \mathrm{NaCl} / \mathrm{kg}$ initial d.m. Among other phenomena, the US application in liquid media induces cavitation, temperature gradients within the material, alternative compression and decompression of the material, the 
generation of microchannels and microstirring on interfaces, which are responsible for the increased gain in $\mathrm{NaCl}$. Cárcel et al. (2007a) and Gabaldón-Leyva et al. (2007) also found significant differences $(\mathrm{p}<0.05)$ in the net increase of dry matter content during the ultrasound assisted osmotic treatment of apple and red bell pepper.

Regarding the moisture content, pork loin showed average initial moisture content of $3.10 \pm 0.12 \mathrm{~kg}$ water $/ \mathrm{kg}$ initial d.m. As can be observed in Fig. 3, the concentration of $\mathrm{NaCl}$ in the brine solution was a key parameter in moisture transport, since it determined the direction of water flux. The ANOVA carried out with samples brined for $120 \mathrm{~min}$ reflected that samples could be classified in three significantly different groups according to the moisture content (Fig. 2 C). The first group included samples brined using 50 and $100 \mathrm{~kg} \mathrm{NaCl} / \mathrm{m}^{3}$, which showed a significant $(\mathrm{p}<0.05)$ water gain. Samples brined using 150 and $200 \mathrm{~kg}$ $\mathrm{NaCl} / \mathrm{m}^{3}$ (the second group) neither lost nor gained water, having similar moisture content to raw meat. This result coincided with what was reported by Graiver et al. (2009) and Nguyen et al. (2010), who did not find a clear moisture transport when using brines close to $200 \mathrm{~kg}$ $\mathrm{NaCl} / \mathrm{m}^{3}$, either. The water activity of meat samples and the $200 \mathrm{~kg} \mathrm{NaCl} / \mathrm{m}^{3}$ brine were 0.980 \pm 0.007 and 0.868 \pm 0.001 respectively (Aqua Lab Serie 3, Decagon Devices, Inc., USA). Therefore, the lack of net moisture transport at this concentration may not to be explained from a water activity point of view. Finally, the third group included samples brined at 240 and $280 \mathrm{~kg} \mathrm{NaCl} / \mathrm{m}^{3}$, which underwent dehydration. During brining however, hydration or dehydration are not only affected by chemical potential gradient (Shi and Le Maguer, 2002) but also by structural changes brought about in the meat by salt gain (Schmidt et al., 2008). On the one side, the low $\mathrm{NaCl}$ content increases the muscle's WHC by protein solubilization, which is known, as aforementioned, the "salting-in" phenomenon (Offer and Trinick, 1983). On the other side, the high $\mathrm{NaCl}$ content reduces the WHC and meat muscle shrinks, which is the "salting-out" phenomenon (Graiver et al., 2006). 
239 Regarding ultrasound effect on moisture content, US and CONTROL brined samples for 120

240 min did not show significant differences. (Fig. 2 D). This fact has been also been observed in

241 ultrasound assisted brining of beef muscles (Pohlman et al., 1997; Jayasooriya et al. 2007)

242 and pork meat (Siró et al. 2009). The negligible effect of ultrasound on water content could be

243 linked to the great variability in moisture content of samples (Fig. 3). In addition, it should be

244 considered that the ultrasound intensity may be not enough to provoke significant differences

245 in water transport due to a minim amount of ultrasonic energy is necessary in the medium,

246 and that threshold could be different for water and $\mathrm{NaCl}$ content. Cárcel et al., (2007 b)

247 reported that in high intensity ultrasound fields, brine could be microinjected into the meat

248 leading to a direct increase of $\mathrm{NaCl}$ and water content.

249

250

251

252

253

254

255

256

257

\subsection{Modeling transport kinetics}

The analysis of the experimental results has been focused on the final salt and moisture content (samples brined for $120 \mathrm{~min}$ ). Modeling the experimental transport kinetics (Figs. 1 and 3) will help to identify whether the brining conditions (US application and/or $\mathrm{NaCl}$ concentration) affect the process rate. The fit of the models to experimental kinetics achieved percentages of explained variance (Table 1) for $\mathrm{NaCl}$ transport ranging from 93 to $99 \%$. These values were lower for moisture transport (81.1 to $95.6 \%$ ), which could indicate a poor fit in this case. However, as can be observed in Fig. 4, there exists a similar trend between calculated and experimental moisture contents, which highlights that the proposed diffusion model was adequate to describe the brining process. The low explained variance provided by the diffusion model in the moisture transport should mostly linked to the great variability of the initial composition of raw meat. Therefore, diffusion could be considered the predominant mass transport mechanism during brining. 
The $D_{s}$ values were similar for all the different brine concentrations tested; a lower figure was only found for all $\mathrm{NaCl}$ concentration of $50 \mathrm{~kg} \mathrm{NaCl} / \mathrm{m}^{3}$, probably due to the structural changes in meat samples brought about by low salt gain. The effective $\mathrm{NaCl}$ diffusivities identified for the CONTROL samples agree closely with the values reported in the literature (Graiver et al., 2006; Vestergaard et al., 2007), which actually range between $2-4 \times 10^{-10} \mathrm{~m}^{2} / \mathrm{s}$. Regarding moisture transport, the $\mathrm{D}_{\mathrm{w}}$ values identified in experiments where meat was hydrated ( $\mathrm{NaCl}$ concentration lower than $200 \mathrm{~kg} \mathrm{NaCl} / \mathrm{m}^{3}$ ) decreased as the $\mathrm{NaCl}$ content rose. Thus, in CONTROL experiments using a brining solution of $50 \mathrm{~kg} \mathrm{NaCl} / \mathrm{m}^{3}$, the $\mathrm{D}_{\mathrm{w}}$ was $0.76 \times 10^{-10} \mathrm{~m}^{2} / \mathrm{s}$, while $D_{\mathrm{w}}$ decreased to $0.17 \times 10^{-10} \mathrm{~m}^{2} / \mathrm{s}$ for experiments at $150 \mathrm{~kg} \mathrm{NaCl} / \mathrm{m}^{3}$, where hydration was almost negligible. The same fact was also observed in US experiments and has also been previously reported by Gou et al., (2003), who found that the $\mathrm{D}_{\mathrm{w}}$ decreased when the $\mathrm{NaCl}$ content of the salting solutions increased from 20 to $80 \mathrm{~kg} \mathrm{NaCl} / \mathrm{m}^{3}$. On the other hand, the $\mathrm{D}_{\mathrm{w}}$ values were higher when meat was dehydrated $(\mathrm{NaCl}$ concentration higher than $200 \mathrm{~kg} \mathrm{NaCl} / \mathrm{m}^{3}$ ) than when meat was hydrated $(\mathrm{NaCl}$ concentration lower than $200 \mathrm{~kg}$ $\mathrm{NaCl} / \mathrm{m}^{3}$ ) (Table 2). It must be clarified that the model was not fit to the experimental data of moisture content obtained for the $200 \mathrm{~kg} \mathrm{NaCl} / \mathrm{m}^{3}$ brine due to no net moisture transport was observed. For this reason, the diffusivity value is not included in Table 2 at this experimental conditions. These differences could be ascribed to the different product structure induced and controlled by $\mathrm{NaCl}$ transport (Schmidt et al., 2008; Gou et al., 2003; Offer and Trinick, 1983). Therefore, the $\mathrm{NaCl}$ concentration in the brining solution is not only affecting the direction of water flux (hydration or dehydration) but also the water transport rate as a consequence of the structural changes brought about by the $\mathrm{NaCl}$ content in the meat.

Ultrasound application led to a significant $(\mathrm{p}<0.05)$ improvement in both $\mathrm{D}_{\mathrm{s}}$ and $\mathrm{D}_{\mathrm{w}}$, which points to an acceleration of both the global bring process. The increase in $\mathrm{D}_{\mathrm{s}}$ ranged from 23 to $45 \%$ and is in a similar range to other improvements reported for solid transport in the 
literature. Thus, Siró et al. (2009) found increases of 96\% in $\mathrm{D}_{\mathrm{s}}$ meat brining and GabaldónLeyva et al. (2007) stated an improvement of $190 \%$ in the total solid diffusion coefficients. In the case of $D_{w}$, the improvement was higher than in $\mathrm{D}_{\mathrm{s}}$ for the lowest and highest $\mathrm{NaCl}$ concentrations used (50 and $280 \mathrm{~kg} \mathrm{NaCl} / \mathrm{m}^{3}$ ) (Table 1), being in this case the improvement close to $100 \%$. Gabaldón-Leyva et al., 2007 and Cárcel et al., 2007a reported increases in $\mathrm{D}_{\mathrm{w}}$ of around 128 and $117 \%$ when ultrasound was applied in bell pepper brining and osmotic dehydration of apple. Smaller increases were observed in the $\mathrm{D}_{\mathrm{w}}$ values for intermediate $\mathrm{NaCl}$ concentration brines tested, these being $76 \%$ and $41 \%$ for 100 and $150 \mathrm{~kg} \mathrm{NaCl} / \mathrm{m}^{3}$, respectively. The different effectiveness of ultrasound application, depending on brine $\mathrm{NaCl}$ concentration, could be explained considering that the ultrasound effects on mass transport are largely dependent on product structure (Gabaldón-Leyva et al., 2007).

Finally, it should be remarked that, as stated before, there was not a significant $(\mathrm{p}<0.05)$ difference on the moisture content at the end of the brining process $(120 \mathrm{~min})$ for CONTROL and US samples, however, the analysis of transport kinetics showed an improvement on the moisture transport rate by ultrasound. The effective moisture diffusivities identified from experimental results are kinetic parameters that not only include diffusion mechanisms but also other existing phenomena not considered in the model, such as external mass transport. Ultrasound may affect both internal mass transport resistance, by alternating cycles of expansions and contractions ("sponge effect") and the generation of microchannels, and external by microstirring at the interfaces (Muralidhara et al., 1985, Cárcel et al., 2007b). These effects that US induce into the medium are responsible for the kinetic improvement.

\subsection{Texture}

In order to study the influence of ultrasound application and $\mathrm{NaCl}$ concentration on meat texture, instrumental penetration tests were carried out in raw material, US $(40 \mathrm{kHz} ; 37.5$ 
$313 \mathrm{~W} / \mathrm{dm}^{3}$ ) and CONTROL samples brined for $120 \mathrm{~min}$ using $\mathrm{NaCl}$ concentrations of 50, 200

314 and $280 \mathrm{~kg} \mathrm{NaCl} / \mathrm{m}^{3}$. At least 12 points were measured in each meat slice.

315 Raw material showed a hardness of $1.60 \pm 0.49 \mathrm{~N}$. With regard to brined samples, the

316 hardness was dependent on the salting conditions used. Thus, CONTROL samples brined at 317200 and $280 \mathrm{~kg} \mathrm{NaCl} / \mathrm{m}^{3}$ were significantly $(\mathrm{p}<0.05)$ harder than those brined at $50 \mathrm{~kg}$ $318 \mathrm{NaCl} / \mathrm{m}^{3}$ (Table 3). As aforementioned, the higher the $\mathrm{NaCl}$ concentration in the brine, the 319 greater the $\mathrm{NaCl}$ gain. In such a way, the $\mathrm{NaCl}$ gain promoted changes in meat texture, 320 leading to harder samples, a fact already showed by Ruiz-Ramírez et al. (2005). Nonsignificant differences $(\mathrm{p}<0.05)$ in hardness were found in samples brined at 200 and $280 \mathrm{~kg}$ $\mathrm{NaCl} / \mathrm{m}^{3}$ (Table 3). This indicates that the level of $\mathrm{NaCl}$ gained by both samples was enough to produce the same change in meat texture. The effect of the $\mathrm{NaCl}$ concentration in US samples was similar to that reported in CONTROL ones.

On the other hand, the application of ultrasound during brining significantly increased $(\mathrm{p}<0.05)$ the meat hardness. As already explained, ultrasound application intensified $\mathrm{NaCl}$ transport during brining, increasing not only the $\mathrm{NaCl}$ diffusivity but also the final $\mathrm{NaCl}$ content (brining time $120 \mathrm{~min}$, CONTROL 0.326 $\pm 0.007 \mathrm{~kg} \mathrm{NaCl} / \mathrm{kg}$ initial d.m. and US 0.409.29 $\pm 0.11 \mathrm{~kg} \mathrm{NaCl} / \mathrm{kg}$ initial d.m.). So, the effects of ultrasound on meat texture could be linked to the intensification of $\mathrm{NaCl}$ transport, which provoked structural changes in meat proteins. Lee and Feng (2011) reported that the texture of ultrasound-treated food is influenced by protein changes during sonication, as well as Siró et al., (2009), who linked the hardening of meat tissue to the high ultrasonic intensities applied. Sanchez et al., (2001) showed that US application in the brining of Mahon cheese increased the sample hardness due to the improvement of proteolysis and lipolysis reactions.

Raw and brined CONTROL and US pork loin previously characterized from instrumental texture were studied by Cryo-SEM and SEM techniques in order to contribute to a better 
understanding of the effects produced by ultrasound application, being this fact analyzed in the following section.

\subsection{Microstructure}

3.4.1. Cryo-scanning electron microscopy (Cryo-SEM)

First of all the microstructure of raw pork loin was characterized. Fig. 5A shows a cross section of the raw pork loin, where cells are surrounded by the membrane or sarcolemma (Fig. 5A, S). These cells are interconnected by endomysial connective tissue (Fig. 5A, EC), which keeps the muscle fibers tightly attached. In addition, the myofibrils inside the muscle cell can be observed, which are fundamental components of the cell's contractile apparatus (Fig. 5A, M).

Intercellular spaces appear full of typical eutectic artifacts in brined samples (Figs. 5B, C and D) due to solute aggregation after water sublimation provoked by Cryo-SEM technique (Pérez-Munuera et al., 2008). The accumulation of solutes in the intercellular spaces can be linked to both the penetration of the $\mathrm{NaCl}$ and the strong solubilization and dehydration in muscle tissue. The greater the brining $\mathrm{NaCl}$ concentration, the greater the solute accumulation and the more compact the eutectic artifacts (Larrea et al., 2007). The bundles of muscle fibers in CONTROL samples brined at $280 \mathrm{~kg} \mathrm{NaCl} / \mathrm{m}^{3}$ (Fig. 5D) seem to be more compact, showing the more intense sample dehydration linked to the "salting-out" phenomenon. The denaturation and precipitation of proteins involves progressive structural shrinkage and less space for water (Vestergaard et al., 2005). These effects are widely related with the hardening observed in the textural analysis of meat brined at the highest $\mathrm{NaCl}$ concentration $(280 \mathrm{~kg}$ $\mathrm{NaCl} / \mathrm{m}^{3}$ ) (Table 3). In samples brined at the lowest $\mathrm{NaCl}$ concentration $\left(50 \mathrm{~kg} \mathrm{NaCl} / \mathrm{m}^{3}\right.$, Fig. 5B), however, may be observed an expansion of myofibrils coupled with the protein solubilization that is related with the "salting-in" phenomena (Graiver et al., 2006). Some 
363

364

365

366

367

368

369

370

371

372

373

374

375

376

377

378

379

380

381

382

383

384

385

386

authors have already reported that an increase in water binding and hydration in the muscle fibers of brined meat at low brine concentrations $\left(<50 \mathrm{~kg} \mathrm{NaCl} / \mathrm{m}^{3}\right)$ is ascribed to enhanced electrostatic repulsion between myofibril filaments causing the filament lattice to expand for water entrapment (Graiver et al., 2009; Cheng and Sun, 2008). These phenomena in meat proteins can explain the hydration of samples brined at low $\mathrm{NaCl}$ concentrations (Fig. 3) and the meat softening observed in the textural analysis (Table 3).

Samples brined with $200 \mathrm{~kg} \mathrm{NaCl} / \mathrm{m}^{3}$ (Fig. 5C), showed a mixed effect. Some parts of the sample show structural dehydration due to a high $\mathrm{NaCl}$ concentration (Fig. 5C, 1), whereas in other parts of the sample, the opposite phenomena (hydration) can be observed in the myofibrillar structure (Fig. 5C, 2). As mentioned before (Fig. 3), no net transport of moisture was identified at $200 \mathrm{~kg} \mathrm{NaCl} / \mathrm{m}^{3}$, which can be linked to the combined effect of hydrationdehydration observed in the meat microstructure (Fig. 5C).

From micrographs obtained with Cryo-SEM, no effects of ultrasound in the meat structure were found. Thus, the Cryo-SEM microstructural analysis was completed with SEM observations.

1.1.1. Scanning electron microscopy (SEM) with combined dispersion X-ray analysis (SEM-EDX).

CONTROL samples brined with the lowest $\mathrm{NaCl}$ concentration tested $\left(50 \mathrm{~kg} \mathrm{NaCl} / \mathrm{m}^{3}\right.$, Fig. 6B) showed a swelling of muscle fibers (width $87.6 \pm 7.3 \mu \mathrm{m}$ ) compared to raw meat (width $72.5 \pm 9.1 \mu \mathrm{m})$ (Fig. 6A). The swelling of muscle fibers could be mainly ascribed to the'saltingin" phenomena. Samples brined at higher $\mathrm{NaCl}$ concentrations $(280 \mathrm{~kg} \mathrm{NaC}$ lakg behaved in the opposite way and presented a dehydration of muscle fibers and an accumulation of $\mathrm{NaCl}$; these effects may be observed in Figs. 7A, C, E. 
The SEM technique also allowed the effect brought about by high intensity ultrasound in meat structure to be observed, this effect mainly focusing on myofibrils (Figs. 7B, D, F). The micrograph of the US sample brined at $50 \mathrm{~kg} \mathrm{NaCl} / \mathrm{m}^{3}$ (Fig. 7B) shows the disruption and the dispersion of the connective tissue of the fibers caused by US application. In Fig. 7F the rupture of a myofibril provoked by the acoustic energy was identified. The aforementioned myofibrillar changes could be explained by the alternating compressions and decompressions induced by US in solid materials ("sponge effect"). Another important effect produced by high intensity ultrasound in liquid media is cavitation, which may be observed in Fig. 7D, where the erosion of meat fiber produced by cavitation is shown. The asymmetric implosion of bubbles near the solid surface could produce violent microjets that collide with the samples, which can improve mass transfer by disturbing the boundary layer and producing changes in the meat structure. These results coincide with those found by several authors that related the application of high power ultrasound with the physical disruption of cellular and sub-cellular components (Reynolds et al., 1978), the degradation of collagen macromolecules (Nishira and Doty, 1958), and the creation of micro channels (Muralidhara et al., 1985).

The obtained SEM-EDX mapping images confirmed the presence of $\mathrm{NaCl}$ in meat after brining, which is shown up by the red $\left(\mathrm{Cl}^{-}\right)$and green $\left(\mathrm{Na}^{+}\right)$dots in the micrographs. As can be observed in Fig. 8, the $\mathrm{NaCl}$ concentration in US samples (Figs. 8B, D and F) was higher than those observed in CONTROL samples, as manifested by a higher number of dots in the micrographs (Figs. 8A, C and E). In CONTROL samples (Figs. 8A, C and E), $\mathrm{NaCl}$ molecules are mainly located around the myofibrils. However, the US brined samples (Figs. $8 \mathrm{~B}, \mathrm{D}$ and $\mathrm{F}$ ) showed a more homogeneous $\mathrm{NaCl}$ dispersion due to the collapse of myofibrillar structure caused by the effects of high power ultrasound, permitting a higher $\mathrm{NaCl}$ penetration in the meat. The obtained SEM-EDX images showed the intensification of 
$411 \mathrm{NaCl}$ transport brought about by US application and the increase in $\mathrm{NaCl}$ content, which

412 confirms the results provided by modeling and textural tools.

413 Therefore, ultrasound application could improve the brining process by reducing the brining

414 time, involving a faster and more uniform distribution of sodium chloride. In this sense, this

415 technology could be an interesting alternative to reduce $\mathrm{NaCl}$ levels in dry-cured meat foods.

416

417

418

419

420

\section{Conclusions}

The $\mathrm{NaCl}$ concentration in the brine solution significantly $(\mathrm{p}<0.05)$ affected moisture and $\mathrm{NaCl}$ transport during meat brining. At $\mathrm{NaCl}$ concentrations lower than $200 \mathrm{~kg} \mathrm{NaCl} / \mathrm{m}^{3}$, the meat was hydrated while, dehydration took place at concentrations higher than $200 \mathrm{~kg}$ $\mathrm{NaCl} / \mathrm{m}^{3}$. As for the $\mathrm{NaCl}$ transport, the more concentrated the brine, the greater the $\mathrm{NaCl}$ sample gain. Ultrasound application intensified the brining kinetics, increasing both moisture effective and $\mathrm{NaCl}$ diffusivities. The $\mathrm{NaCl}$ gain promoted changes in meat texture, high $\mathrm{NaCl}$ contents leading to harder samples. Microstructural analyses showed that the application of high intensity ultrasound during brining brought about relevant effects on meat microstructure, such as a more homogeneous $\mathrm{NaCl}$ distribution in meat. Therefore, ultrasound could be considered a potential technology with which to accelerate the brining process.

\section{Acknowledgments}

This work is financed by project CARNISENUSA (CSD2007-00016) included in the CONSOLIDER-INGENIO-2010. 


\section{Nomenclature}

$\mathrm{W}_{\mathrm{eq}} \quad$ Equilibrium moisture content, $\mathrm{kg}$ water/kg initial d.m.

$\mathrm{W}_{0} \quad$ Initial moisture content, $\mathrm{kg}$ water/kg initial d.m.

$\mathrm{S}_{\mathrm{eq}} \quad$ Equilibrium sodium chloride content, $\mathrm{kg} \mathrm{NaCl} / \mathrm{kg}$ initial d.m.

$\mathrm{S}_{0} \quad$ Initial sodium chloride content, $\mathrm{kg} \mathrm{NaCl} / \mathrm{kg}$ initial d.m.

$\mathrm{D}_{\mathrm{S}} \quad$ Effective $\mathrm{NaCl}$ diffusivity $\left(\mathrm{m}^{2} / \mathrm{s}\right)$

$\mathrm{D}_{\mathrm{w}} \quad$ Effective moisture diffusivity $\left(\mathrm{m}^{2} / \mathrm{s}\right)$

L Half length, m 


\section{References}

Asociación de industrias de la carne de España (AICE), available online http://www.aice.es. Accesed on November 01, 2011.

Association of Official Analytical Chemists. Official Methods of Analysis; AOAC: Washington, DC, 1997.

Barat, J.M., Grau, R., Ibáñez, J.B., Pagán, M.J., Flores M., Toldrá F., \& Fito P. (2006). Accelerated processing of dry-cured ham. Part I. Viability of the use of brine thawing/salting operation. Meat Science, 72 (4), 757-765.

Cárcel, J.A., Benedito, J., Roselló, C., \& Mulet, A. (2007a). Influence of ultrasound intensity on mass transfer in apple immersed in a sucrose solution. Journal of Food Engineering, 78 (2), 472-479.

Cárcel, J.A., Benedito, J., Bon, J., \& Mulet A. (2007b). High intensity ultrasound effects on meat brining. Meat Science, 76 (4), 611-619.

Cheng, Q., \& Sun, D.-W. (2008). Factors affecting the water holding capacity of red meat products: a review of recent research advances. Critical Reviews in Food Science and Nutrition, 48 (2), 137-159.

Crank, J. (1975). The Mathematics of Diffusion. London: Oxford University Press.

Gabaldón-Leyva, C. A., Quintero-Ramos, A., Barnard, J., Balandrán-Quintana, R. R., Talamás-Abbud, R. T., \& Jiménez-Castro, J. (2007). Effect of ultrasound on the mass transfer and physical changes in brine bell pepper at different temperature. Journal of Food Engineering, 81(2), 374-379.

Gou, P., Comaposada, J., \& Arnau, J. (2003). NaCl content and temperature effects on moisture diffusivity in the Gluteus medius muscle of pork ham. Meat Science, 63 (1), 29-34. 
Graiver, N., Pinotti, A., Califano, A., \& Zaritzky, N. (2006). Diffusion of sodium chloride in pork tissue. Journal of Food Engineering, 77 (4), 910-918.

Graiver, N., Pinotti, A., Califano, A., \& Zaritzky, N. (2009). Mathematical modeling of the uptake of curing salts in pork meat. Journal of Food Engineering, 95 (4), 533-540.

Grote, M. \& Georg, H. (1984) Determination of element concentrations in fresh and processed vegetables by quantitative X-ray microanalysis. Food Microstructure, 3 (1), $49-54$.

Jayasooriya S.D., Torley P.J., D’Arcy B.R. \& Bhandari B.R. (2007). Effect of high power ultrasound and ageing on the physical properties of bovine Semitendinous and Longissimus muscles. Meat Science, 75 (4), 628-639.

Larrea, V., Pérez-Munuera, I., Hernardo, I., Quiles, A., Llorca, E., \& Lluch, M.A. (2007). Microstructural changes in Teruel dry-cured ham during processing. Meat Science, 76 (3), 574-582.

Lee, H. \& Feng, H. (2011). Effect of power ultrasound on food quality. In Feng, H., BarbosaCánovas, G.M. \& Weiss, J. (Eds.), Ultrasound Technologies for Food and Bioprocessing (pp. 559-582). London: Springer.

Leighton, T. G. (1998). The principles of cavitation. In M. J. W. Povey \& T. J. Mason (Eds.), Ultrasound in Food Processing (pp. 151-182). London: Chapman \& Hall.

Llorca, E., Puig, A., Hernando, I., Salvador, A., Fiszman S., \& Lluch, M.A. (2001). Effect of fermentation time on texture and microstructure of pickled carrots. Journal of the Science of Food and Agriculture, 81 (15), 1553-1560.

Mason, T. J., \& Lorimer, J. P. (2002). Applied sonochemistry. The uses of power ultrasound in chemistry and processing. Weinheim: Wiley-VCH.

Muralidhara, H. S., Ensminger, D., \& Putnam, A. (1985). Acoustic dewatering and drying (low and high frequency): State of the art review. Drying Technology, 3(4), 529-566. 
Nguyen, M.V., Arason, A., Thorarinsddottir, K.A., Thorkelsson, G. \& Gudmundsdóttir, A. (2010). Influence of salt concentration on the salting kinetics of cod loin (Gadus morhua) during brine salting. Journal of Food Engineering, 100 (2), 225-231.

Nishira, T., \& Doty, P. (1958). The sonic fragmentation of collagen macromolecules. Proceedings of the National Academy of Sciences of the United States of America, 44(5), 411-417.

Offer, G. \& Trinick, J. (1983). On the mechanism of water holding in meat: The swelling and shrinking of myofibrils. Meat Science, 8 (4), 245-281.

Pérez-Munuera, I., Larrea, V., Quiles, A., \& Lluch, M.A. (2008). Microstructure of muscle foods. In L.M.L., Nollet \& F. Toldrá (Eds.), Handbook of muscle food analysis (pp. 335-352). Boca Raton FL: CRC Press Taylor \& Francis Group.

Pohlman, F.W, Dikeman M.E., \& Kropf D.H. (1997). Effects of high intensity ultrasound treatment, storage time and cooking method on shear, sensory, instrumental color and cooking properties of packaged and unpackaged beef pectoralis muscle, Meat Science, $46(1), 89-100$.

Rastogi, N.K., Raghavarao, K.S.M.S., Niranjan, K., \& Knorr, D. (2002). Recent developments in osmotic dehydration: methods to enhance mass transfer. Trends in Food Science \& Technology, 13 (2), 48-59.

Reynolds, J.B., Anderson D.B., Schmidt, G.R., Theno, D.M., \& Siegel D.G. (1978). Effects of ultrasonic treatment on binding strength in cured ham rolls. Journal of Food Science, 43 (3), 866-869.

Ruiz-Ramírez, J., Arnau, J., Serra, X., \& Gou, P. (2005). Relationship between water content, $\mathrm{NaCl}$ content, $\mathrm{pH}$ and texture parameters in dry-cured muscles. Meat Science, 70 (4), $579-587$. 
512 Sanchez, E. S., Simal, S., Femenía, A., Benedito, J. \& Roselló, C. (2001). Effect of acoustic

513

514

515

516

517

518

519

520

521

522

523

524

525

526

527

528

529

530

531

532

533

534 brining on lipolysis and on sensory characteristics of Mahon cheese. Journal of Food Science, 66(6), 892-896.

Schmidt, F.C., Carciofi, B.A.M. \& Laurindo, J. B. (2008). Salting operational diagrams for chicken breast cuts: Hydration-dehydration. Journal of Food Engineering, 88 (1), 3644.

Shi J. \& Le Maguer M. (2002). Osmotic dehydration of foods: mass transfer and modelling aspects. Food Reviews International, 18(4), 305-335.

Siró, I., Vén, C., Balla, C., Jónás, G., Zeke, I., \& Friedrich, L. (2009). Application of an ultrasonic assisted curing technique for improving the diffusion of sodium chloride in porcine meat. Journal of Food Science, 91 (2), 363-362.

Vercet, A., Sánchez, C., Burgos, J., Montañés, L., \& Buesa, P. L. (2002). The effects of manothermosonication on tomato pectic enzymes and tomato paste rheological properties. Journal of Food Engineering, 53 (3), 273-278.

Vestergaard, C., Lohmann Andersen, B., \& Adler-Nissen, J. (2007). Sodium diffusion in cured pork determined by ${ }^{22} \mathrm{Na}$ radiology. Meat Science, 76 (2), 258-265.

Vestergaard, C., Risum, J., \& Adler-Nissen, J. (2005). ${ }^{23}$ Na-MRI quantification of sodium and water mobility in pork during brine curing. Meat Science, 69 (4), 663-672.

Wu, H., Hulbert, G. J., \& Mount, J. R. (2000). Effects of ultrasound on milk homogenization and fermentation with yogurt starter. Innovative Food Science and Emerging Technologies, 1 (13), 211-218. 


\section{Figure captions}

Fig 1. Experimental $\mathrm{NaCl}$ transport kinetics in pork loin slices (thickness $10 \mathrm{~mm}$ ) brined at different $\mathrm{NaCl}$ concentrations with (US, $40 \mathrm{kHz}, 37.5 \mathrm{~W} / \mathrm{dm}^{3}$ ) and without ultrasound application (CONTROL). In this figure, each point represents the average of 9 measurements: three independently brined samples analyzed in triplicate. Average \pm standard deviation being plotted.

Fig 2. Least Significant Difference intervals $(\mathrm{p}<0.05)$ for moisture and $\mathrm{NaCl}$ contents of pork loin slices (thickness $10 \mathrm{~mm}$ ) brined at $5 \pm 1{ }^{\circ} \mathrm{C}$ for $120 \mathrm{~min}$ with different brine concentrations with (US, $40 \mathrm{kHz}, 37.5 \mathrm{~W} / \mathrm{dm}^{3}$ ) and without ultrasound application (CONTROL). Dotted line (---) represents the average initial moisture content of pork loin.

Fig 3. Experimental moisture transport kinetics in pork loin slices (thickness $10 \mathrm{~mm}$ ) brined at different $\mathrm{NaCl}$ concentrations with (US, $40 \mathrm{kHz}, 37.5 \mathrm{~W} / \mathrm{dm}^{3}$ ) and without ultrasound application (CONTROL). In this figure, each point represents the average of 9 measurements: three independently brined samples analyzed in triplicate. Average \pm standard deviation being plotted.

Fig 4. Experimental vs calculated moisture content of pork loin slices (thickness 10 $\mathrm{mm}$ ) brined with (US, $40 \mathrm{kHz}, 37.5 \mathrm{~W} / \mathrm{dm}^{3}$ ) and without (CONTROL) ultrasound application. 
Fig 5. Cross-section of Longissimus dorsi muscle of pork meat observed by Cryo-SEM (x 750). Raw meat (A), meat brined for 120 min in $50 \mathrm{~kg} \mathrm{NaCl} / \mathrm{m}^{3}$ (B), $200 \mathrm{~kg} \mathrm{NaCl} / \mathrm{m}^{3}$ (D) and $280 \mathrm{~kg} \mathrm{NaCl} / \mathrm{m}^{3}$. S: sarcolemma, EC: endomysial connective tissue, $\mathrm{M}$ : myofibrills, 1: "salting-out effects", 2: "salting-in effects".

Fig 6. Longitudinal section of Longissimus dorsi muscle of pork meat observed by SEM (x500). Raw meat (A) and meat brined in $50 \mathrm{~kg} \mathrm{NaCl} / \mathrm{m}^{3}$ for $120 \mathrm{~min}(\mathrm{~B})$.

Fig 7. Longitudinal section observed by SEM of Longissimus dorsi muscle of pork meat brined for $120 \mathrm{~min}$ in $50 \mathrm{~kg} \mathrm{NaCl} / \mathrm{m}^{3}$ (A,B: x1500), $200 \mathrm{~kg} \mathrm{NaCl} / \mathrm{m}^{3}$ (C,D: x150) and $280 \mathrm{~kg} \mathrm{NaCl} / \mathrm{m}^{3}$ solution (D, E: x750) without (CONTROL: A, C and E) and with (US: B, D and E) ultrasound application $\left(40 \mathrm{kHz}, 37.5 \mathrm{~W} / \mathrm{dm}^{3}\right) . \mathrm{CV}$ : impact of cavitation buble implosion on myofibrill.

Fig 8. Effect of ultrasound application on $\mathrm{NaCl}$ dispersion. Longitudinal section observed by SEM-EDX of Longissimus dorsi of pork meat brined for $120 \mathrm{~min}$ in $50 \mathrm{~kg}$ $\mathrm{NaCl} / \mathrm{m}^{3}$ (A,B: x500), $200 \mathrm{~kg} \mathrm{NaCl} / \mathrm{m}^{3}$ (C,D: x500) and $280 \mathrm{~kg} \mathrm{NaCl} / \mathrm{m}^{3}$ (D,E: x 150) without (CONTROL: A, C and E) and with (US: B, D and E) ultrasound application $\left(40 \mathrm{kHz}, 37.5 \mathrm{~W} / \mathrm{dm}^{3}\right)$. 

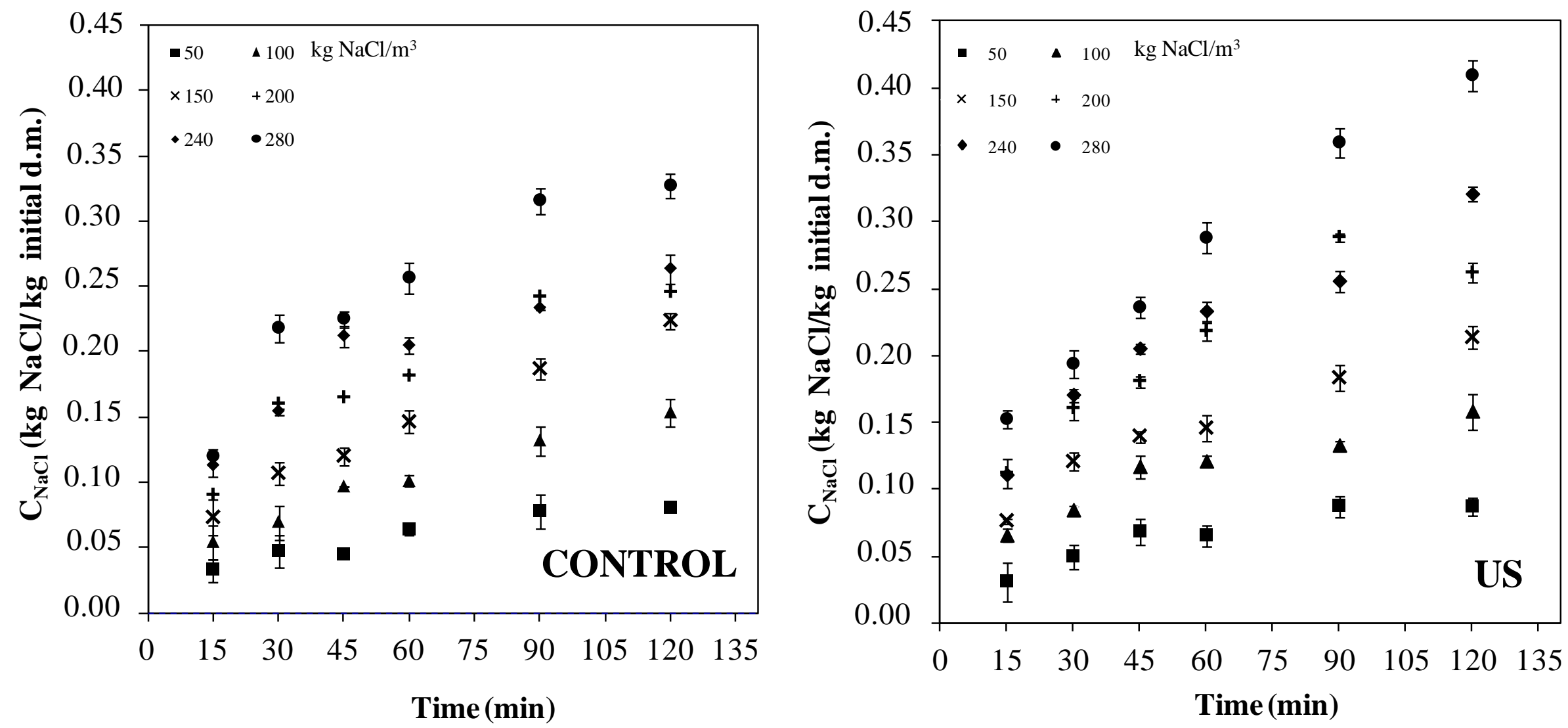

Fig 1. Experimental $\mathrm{NaCl}$ transport kinetics in pork loin slices (thickness $10 \mathrm{~mm}$ ) brined at different $\mathrm{NaCl}$ concentrations with (US, $40 \mathrm{kHz}, 37.5$ $\mathrm{W} / \mathrm{dm}^{3}$ ) and without ultrasound application (CONTROL). In this figure, each point represents the average of 9 measurements: three independently brined samples analyzed in triplicate. Average \pm standard deviation being plotted 

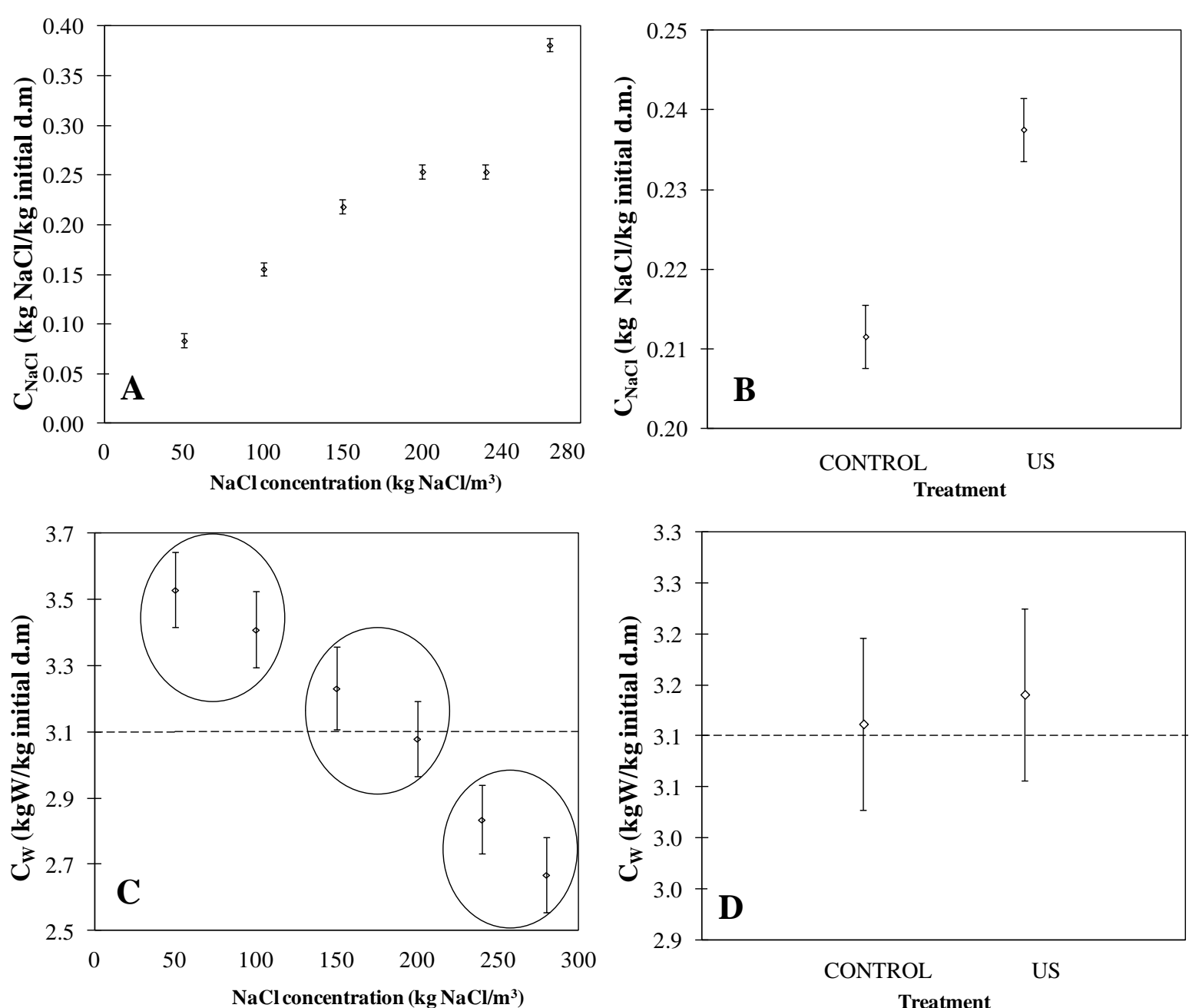

1

2 Fig 2. LSD intervals $(\mathrm{p}<0.05)$ for moisture and $\mathrm{NaCl}$ contents of pork loin slices (thickness $10 \mathrm{~mm}$ ) brined at $5 \pm 1{ }^{\circ} \mathrm{C}$ for $120 \mathrm{~min}$ with different brine concentrations with (US, $40 \mathrm{kHz}, 37.5 \mathrm{~W} / \mathrm{dm}^{3}$ ) and without ultrasound application (CONTROL). Dotted line (---) represents the average initial moisture content of pork loin 

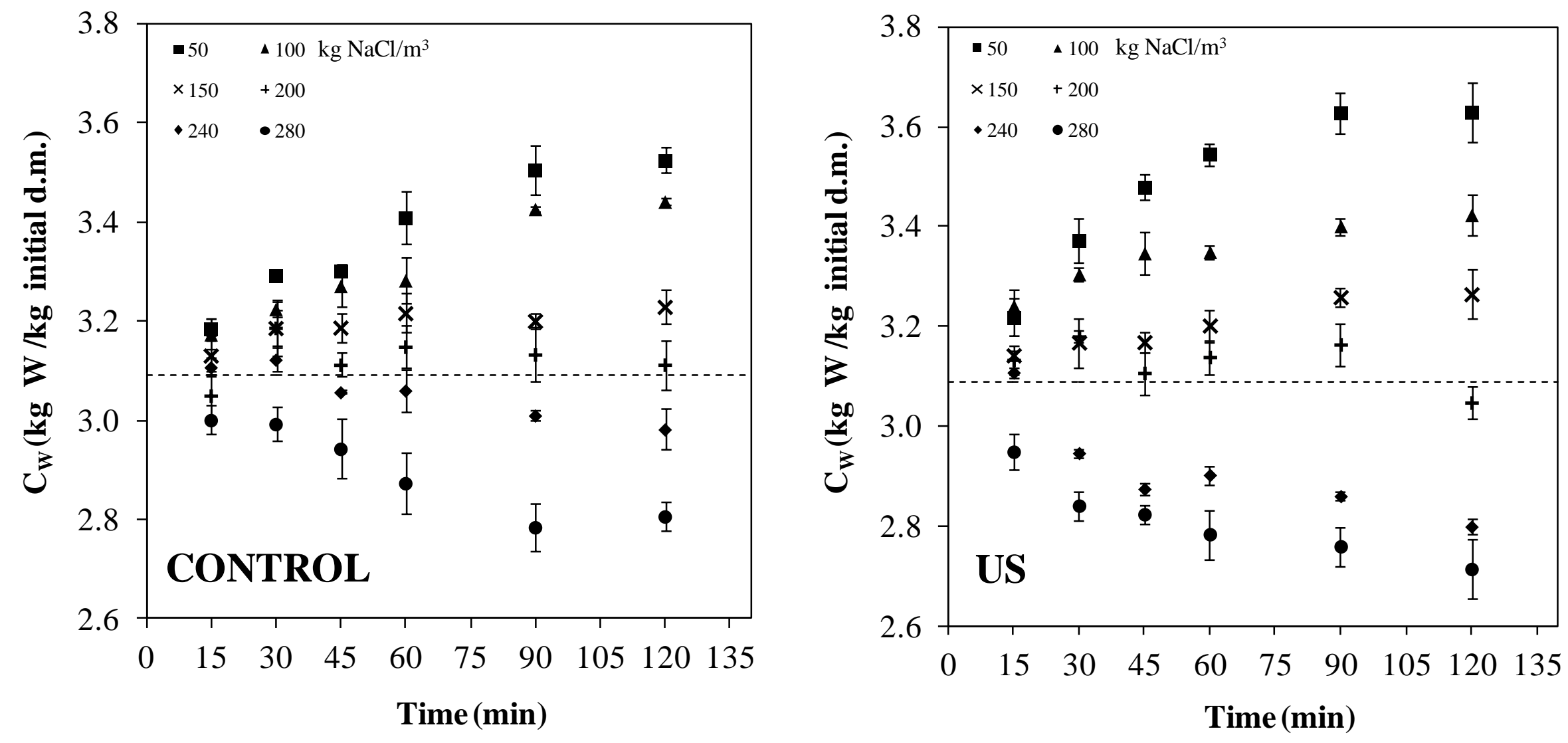

3

Fig 3. Experimental moisture transport kinetics in pork loin slices (thickness $10 \mathrm{~mm}$ ) brined at different $\mathrm{NaCl}$ concentrations with (US, $40 \mathrm{kHz}$, $37.5 \mathrm{~W} / \mathrm{dm}^{3}$ ) and without ultrasound application (CONTROL). In this figure, each point represents the average of 9 measurements: three independently brined samples analyzed in triplicate. Average \pm standard deviation being plotted 

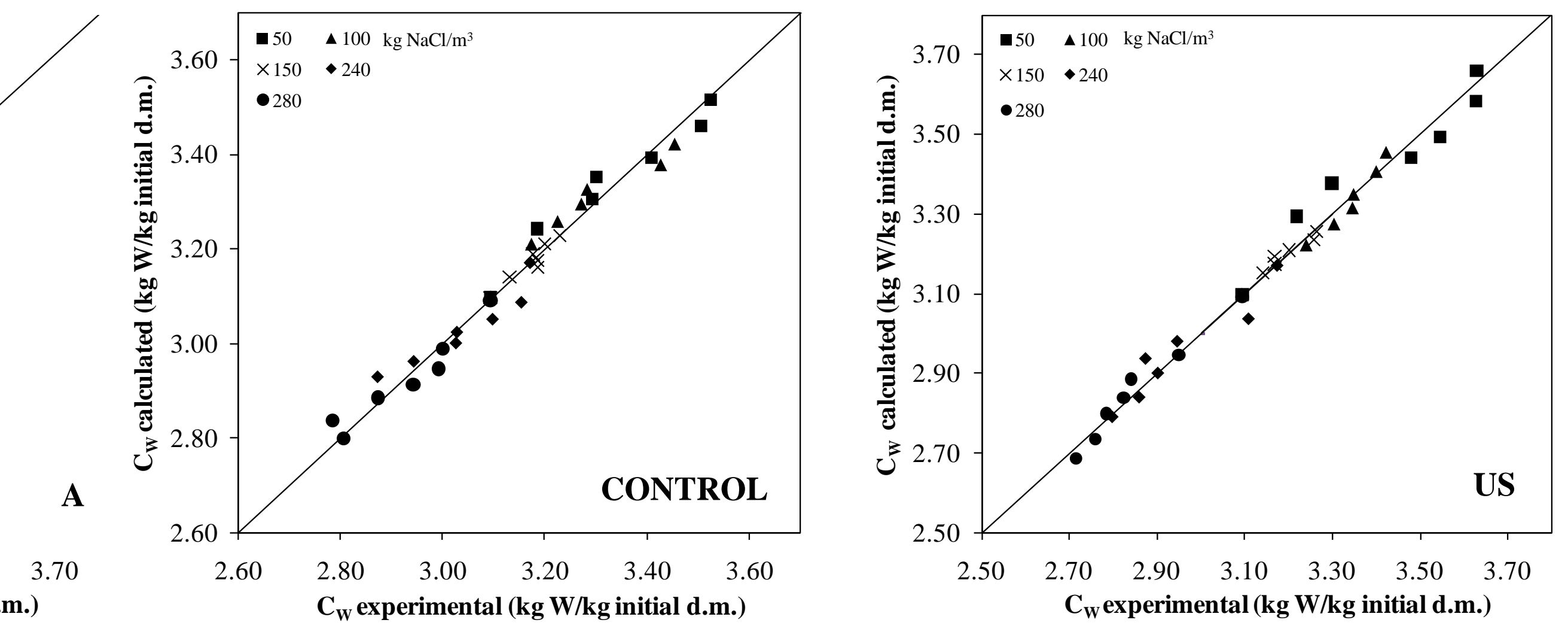

Fig 4. Experimental vs calculated moisture content of pork loin slices (thickness $10 \mathrm{~mm}$ ) brined with (A) and without (B) ultrasound application 

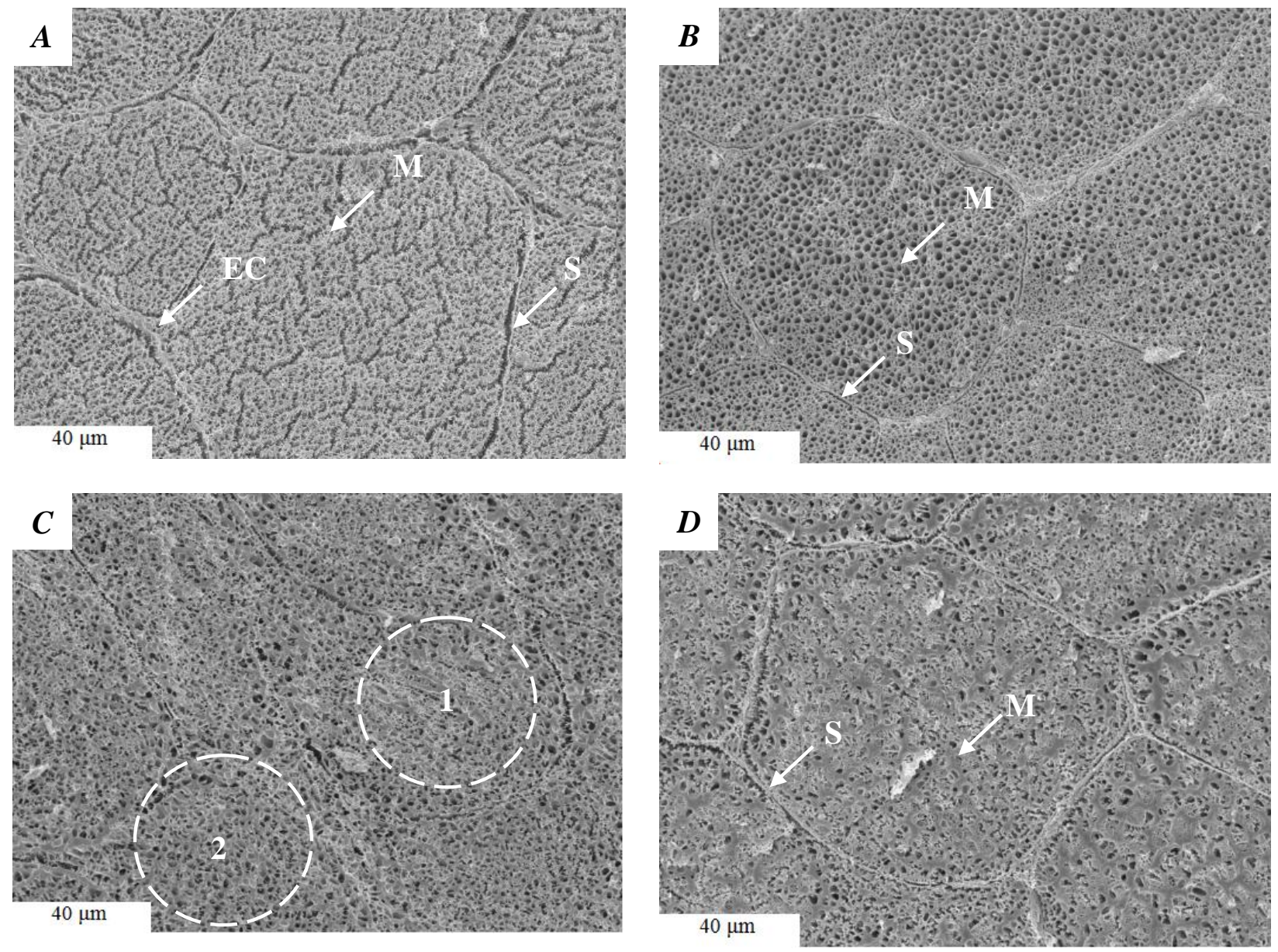

Fig 5. Cross-section of Longissimus dorsi muscle of pork meat observed by Cryo-SEM (x 750). Raw meat (A), meat brined for 120 min in $50 \mathrm{~kg} \mathrm{NaCl} / \mathrm{m}^{3}$ (B), $200 \mathrm{~kg} \mathrm{NaCl} / \mathrm{m}^{3}$ (D) and $280 \mathrm{~kg} \mathrm{NaCl} / \mathrm{m}^{3}$. S: sarcolemma, EC: endomysial connective tissue, $\mathrm{M}$ : myofibrills, 1: "salting-out effects", 2: "salting-in effects" 
Figure 6
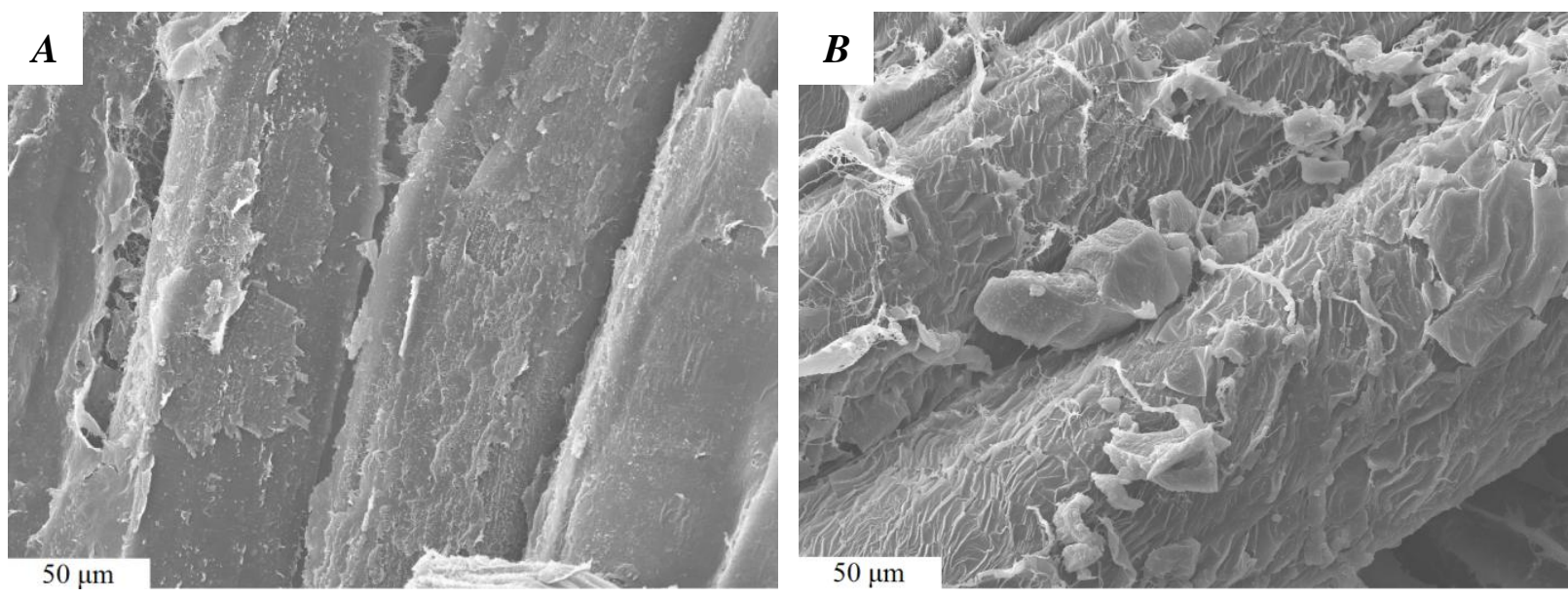

Fig 6. Longitudinal section of Longissimus dorsi muscle of pork meat observed by SEM (x500). Raw meat (A) and meat brined in $50 \mathrm{~kg} \mathrm{NaCl} / \mathrm{m}^{3}$ for $120 \mathrm{~min}$ (B). 
CONTROL
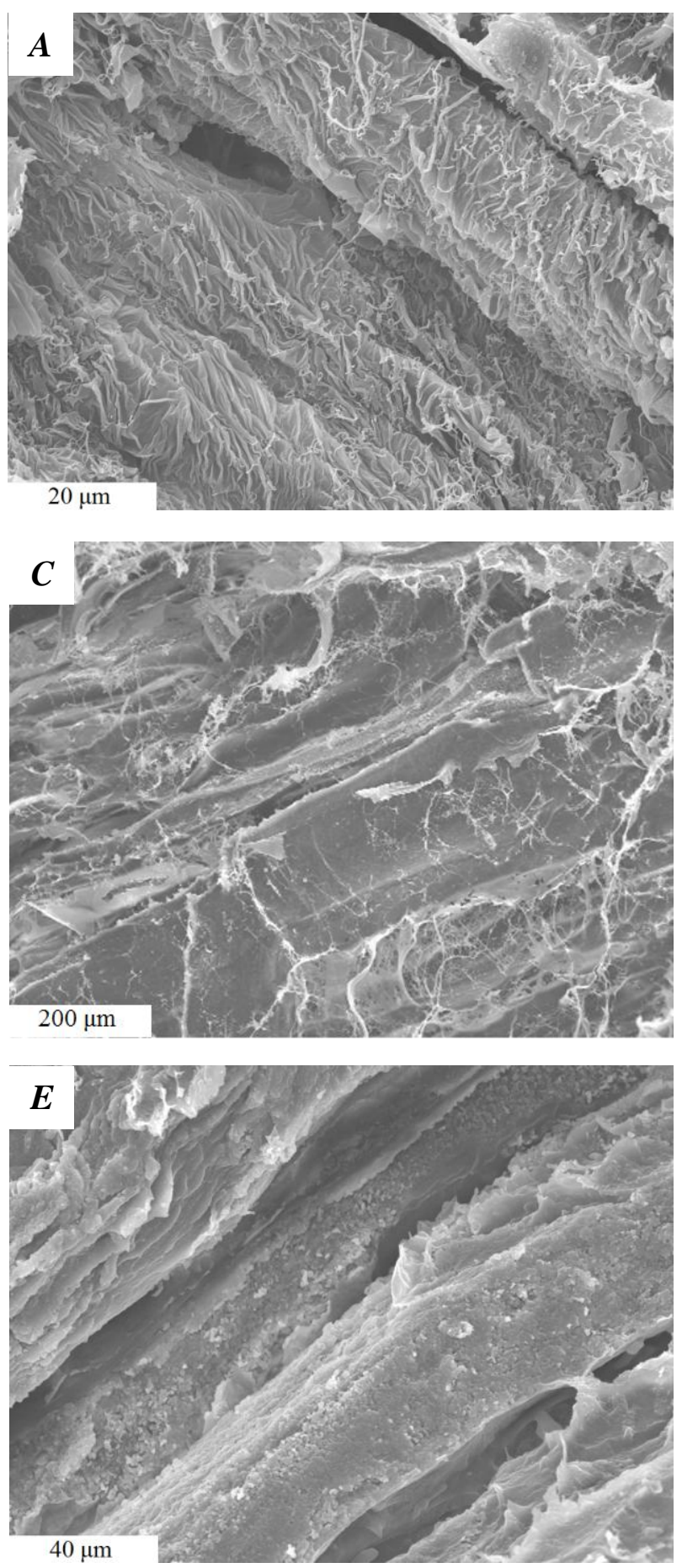

US
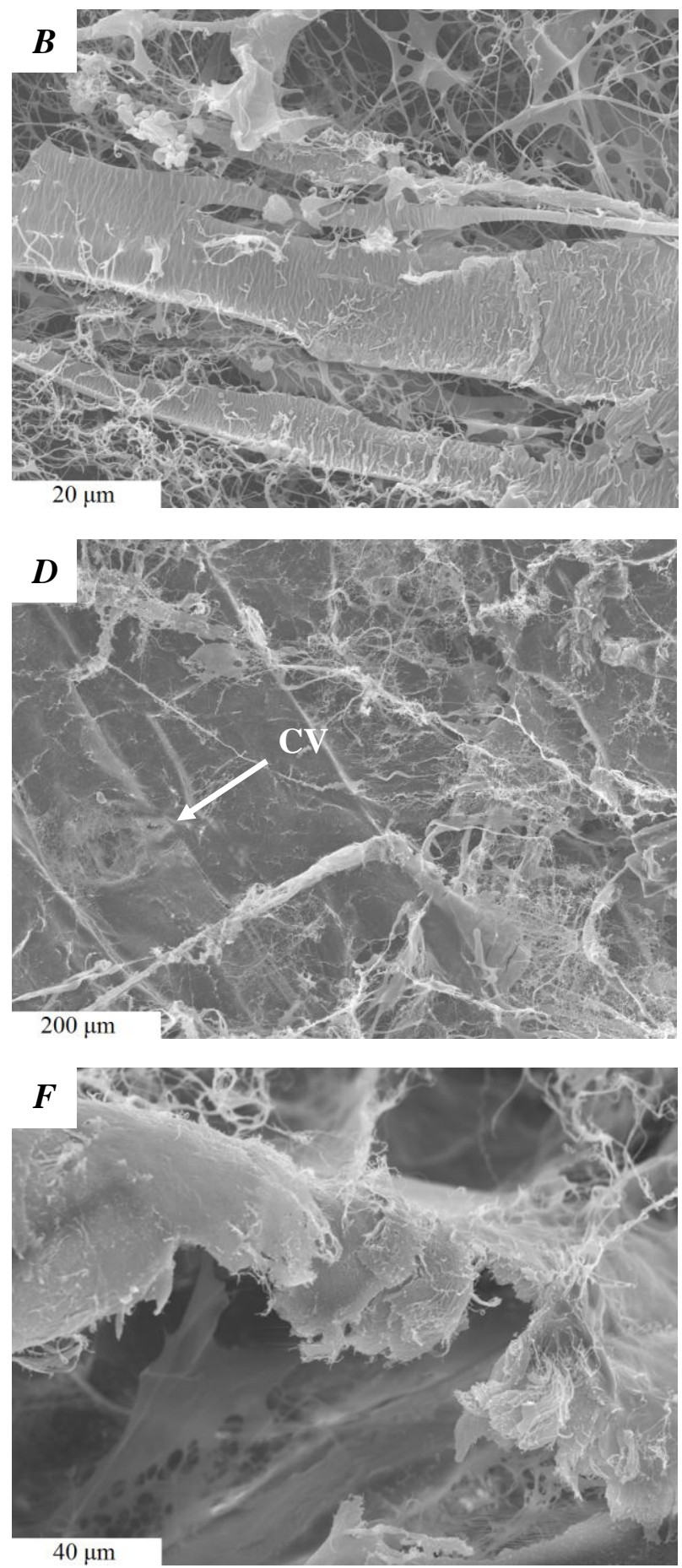

Fig 7. Longitudinal section observed by SEM of Longissimus dorsi muscle of pork meat brined for $120 \mathrm{~min}$ in $50 \mathrm{~kg} \mathrm{NaCl} / \mathrm{m}^{3}$ (A,B: x1500), $200 \mathrm{~kg} \mathrm{NaCl} / \mathrm{m}^{3}$ (C,D: x150) and $280 \mathrm{~kg} \mathrm{NaCl} / \mathrm{m}^{3}$ solution (D, E: x750). CV: impact of cavitation buble implosion on myofibrill 
CONTROL
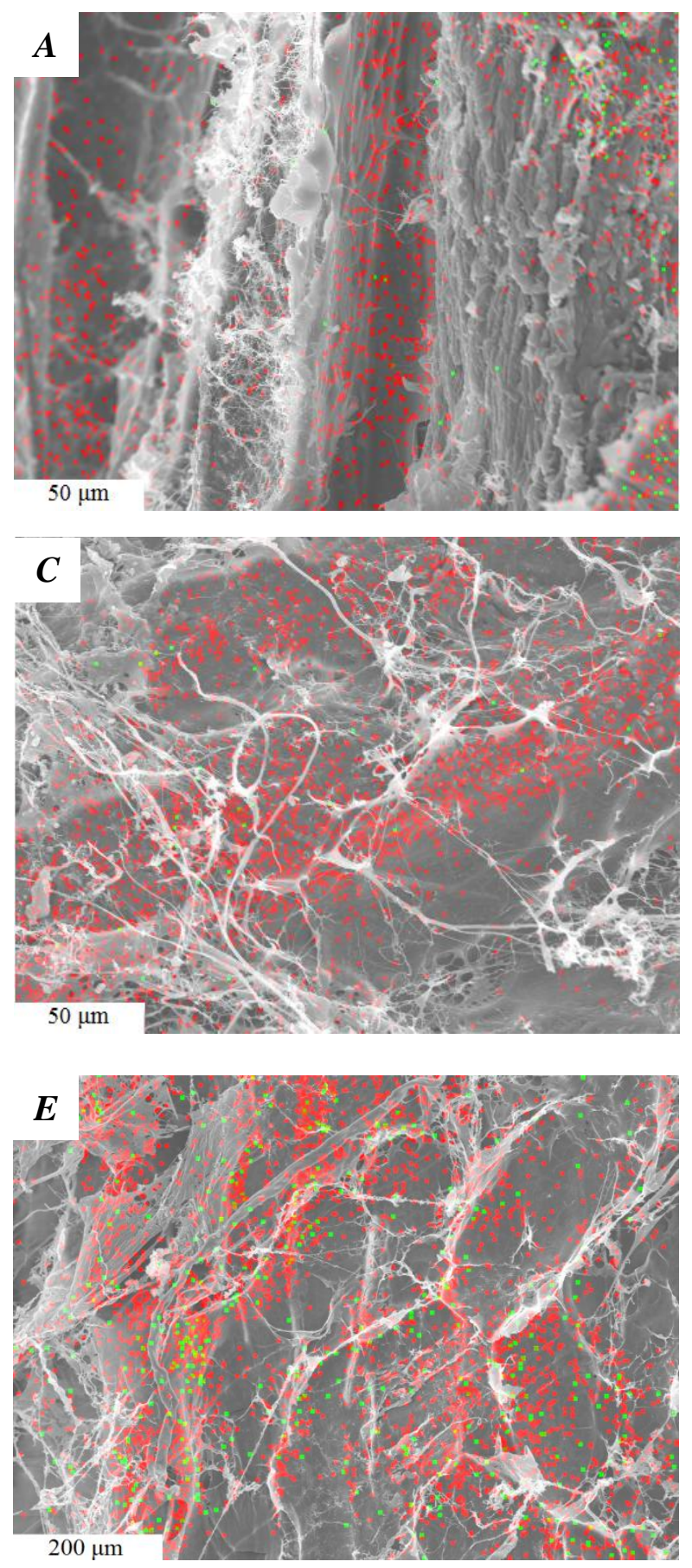

US
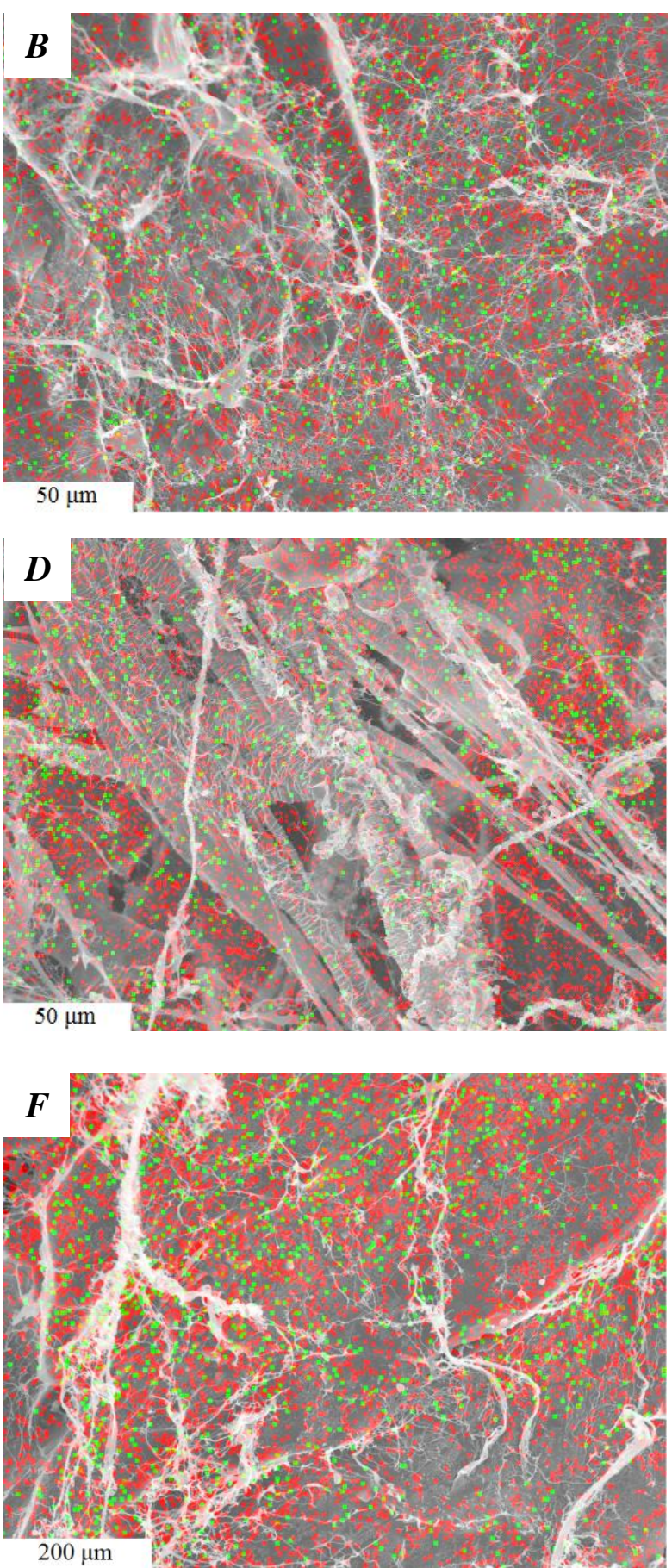

Fig 8. Effect of ultrasound application on $\mathrm{NaCl}$ dispersion. Longitudinal section observed by SEM-EDX of Longissimus dorsi of pork meat brined for $120 \mathrm{~min}$ in $50 \mathrm{~kg}$ $\mathrm{NaCl} / \mathrm{m}^{3}$ (A,B: x500), $200 \mathrm{~kg} \mathrm{NaCl} / \mathrm{m}^{3}$ (C,D: x500) and $280 \mathrm{~kg} \mathrm{NaCl} / \mathrm{m}^{3}$ (D,E: x150) 


\section{Table captions}

2

3 Table 1. Modeling $\mathrm{NaCl}$ transport in pork meat brining $\left(5 \pm 1{ }^{\circ} \mathrm{C}\right)$ at different $\mathrm{NaCl}$

4 concentrations with (US, $40 \mathrm{kHz}, 37.5 \mathrm{~W} / \mathrm{dm}^{3}$ ) and without (CONTROL) ultrasound 5 application. Effective diffusivity and percentage of explained variance. Average \pm confidence 6 intervals of the estimation (significance level 95\%) are shown.

7

8 Table 2. Modeling moisture transport in pork meat brining $\left(5 \pm 1{ }^{\circ} \mathrm{C}\right)$ at different $\mathrm{NaCl}$ 9 concentrations with (US, $40 \mathrm{kHz}, 37.5 \mathrm{~W} / \mathrm{dm}^{3}$ ) and without (CONTROL) ultrasound application. Effective diffusivity and percentage of explained variance. Average \pm confidence intervals of the estimation (significance level 95\%) are shown.

Table 3. Hardness (N) of pork meat brined for $120 \mathrm{~min}$ in different $\mathrm{NaCl}$ concentrations with (US, $40 \mathrm{kHz}, 37.5 \mathrm{~W} / \mathrm{dm}^{3}$ ) and without (CONTROL) ultrasound application. Average \pm standard deviations are shown. Subscripts (a,b,c,d) show homogeneous group established from LSD intervals $(\mathrm{p}<0.05)$. 


\begin{tabular}{cccccc}
\hline $\begin{array}{c}\text { NaCl concentration } \\
\left(\mathrm{kg} / \mathrm{m}^{3}\right)\end{array}$ & $\mathrm{D}_{\mathrm{s}}\left(10^{-10} \mathrm{~m}^{2} / \mathrm{s}\right)$ & $\%$ VAR & $\mathrm{D}_{\mathrm{s}}\left(10^{-10} \mathrm{~m}^{2} / \mathrm{s}\right)$ & $\%$ VAR & $(\%)$ \\
\hline 50 & $1.24 \pm 0.11$ & 98.1 & $1.73 \pm 0.51$ & 97.5 & 40 \\
100 & $2.04 \pm 0.16$ & 99.2 & $2.93 \pm 0.54$ & 96.6 & 44 \\
150 & $2.11 \pm 0.19$ & 99.0 & $2.60 \pm 0.24$ & 98.9 & 23 \\
200 & $1.99 \pm 0.32$ & 96.4 & $2.68 \pm 0.51$ & 95.1 & 35 \\
240 & $1.73 \pm 0.18$ & 96.1 & $2.51 \pm 0.52$ & 93.8 & 45 \\
280 & $1.96 \pm 0.32$ & 96.1 & $2.62 \pm 0.16$ & 99.5 & 34
\end{tabular}

\section{Tables}

\section{Table 1}

22

Table 2

\begin{tabular}{cccccc}
\hline $\begin{array}{c}\text { NaCl concentration } \\
\left(\mathrm{kg} / \mathrm{m}^{3}\right)\end{array}$ & \multicolumn{2}{c}{ CONTROL } & \multicolumn{2}{c}{ US } & Increment \\
\hline 50 & $\mathrm{D}_{\mathrm{W}}\left(10^{-10} \mathrm{~m}^{2} / \mathrm{s}\right)$ & $\%$ VAR & $\mathrm{D}_{\mathrm{W}}\left(10^{-10} \mathrm{~m}^{2} / \mathrm{s}\right)$ & $\%$ VAR & $(\%)$ \\
100 & $0.76 \pm 0.21$ & 90.7 & $1.92 \pm 0.27$ & 91.6 & 153 \\
150 & $0.62 \pm 0.19$ & 90.2 & $1.09 \pm 0.14$ & 94.7 & 76 \\
200 & $0.17 \pm 0.04$ & 89.1 & $0.24 \pm 0.07$ & 92.2 & 41 \\
240 & - & - & - & - & - \\
280 & $1.04 \pm 0.52$ & 81.1 & $2.60 \pm 0.83$ & 88.8 & 150 \\
& $1.83 \pm 0.57$ & 90.0 & $3.67 \pm 0.68$ & 95.6 & 101 \\
\hline
\end{tabular}

24

Table 3 


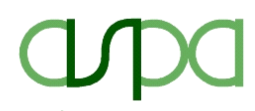

ANÀLISI I SIMUL·LACIÓ

DE PROCESSOS AGROALIMENTARIS
Universidad Politécnica de Valencia Departamento de Tecnología de Alimentos Grupo de Análisis y Simulación de procesos $\mathrm{C} /$ Camino de Vera, s/n 46022, Valencia, SPAIN
Dr. Juan A. Cárcel

Profesor Titular de Universidad

Tel: +34 963879365

Fax: +34 963879839

E-mail: jcarcel@tal.upv.es

\section{Dr. R. P. Singh}

Editor in chief of Journal of Food Engineering

Valencia, October 30, 2012

Dear Editor,

We would like to submit our manuscript "INFLUENCE OF HIGH INTENSITY ULTRASOUND APPLICATION ON MASS TRANSPORT, MICROSTRUCTURE AND TEXTURAL PROPERTIES OF PORK MEAT (Longissimus dorsi) BRINED AT DIFFERENT NaCI CONCENTRATIONS", for your consideration for publication in Journal of Food Engineering, the corresponding author being:

Juan A. Cárcel,

Food Technology Department

Universitat Politecnica de Valencia

$\mathrm{C} /$ Camí de Vera s/n,

46022, Valencia, Spain.

Tel: +34963879365

Fax: +34963877369

E-mail: jcarcel@tal.upv.es

The manuscript is addressing the application of ultrasound at an important stage in industrial meat processing, the brining process. The influence of high intensity ultrasound application on water and salt transport during meat brining using brine solutions with different $\mathrm{NaCl}$ concentrations have been studied. The experimental work has been thoroughly designed and conducted and is appropriate to reach the objectives proposed. The ultrasound effects on water and salt transport kinetics are quantified using mechanistic-diffusion models. Moreover, the meat structure and microstructure changes brought about by ultrasound application have been observed from instrumental texture analysis and Cryo-SEM and SEM techniques. In addition, the structure study has been linked to the kinetic one in order to explain how ultrasound may affect the mass transport during brining. Therefore, we believe the manuscript is an interesting and relevant piece of work useful for authors that are going to deal with ultrasonic applications in mass transfer in food or chemical processing. For this reason, we believe the paper's relevance is well demonstrated and would like to submit it for your consideration. We thank you for your time and interest in our research and look forward to hearing from you.

Yours sincerely

César Ozuna, Ana Puig, Jose V. García-Pérez, Antonio Mulet and Juan A. Cárcel

Authors of the manuscript 


\section{Table captions}

2

3 Table 1. Modeling $\mathrm{NaCl}$ transport in pork meat brining $\left(5 \pm 1{ }^{\circ} \mathrm{C}\right)$ at different $\mathrm{NaCl}$ 4 concentrations with (US, $40 \mathrm{kHz}, 37.5 \mathrm{~W} / \mathrm{dm}^{3}$ ) and without (CONTROL) ultrasound 5 application. Effective diffusivity and percentage of explained variance.

6

7 Table 2. Modeling moisture transport in pork meat brining $\left(5 \pm 1{ }^{\circ} \mathrm{C}\right)$ at different $\mathrm{NaCl}$ 8 concentrations with (US, $40 \mathrm{kHz}, 37.5 \mathrm{~W} / \mathrm{dm}^{3}$ ) and without (CONTROL) ultrasound 9 application. Effective diffusivity and percentage of explained variance.

Table 3. Hardness (N) of pork meat brined for $120 \mathrm{~min}$ in different $\mathrm{NaCl}$ concentrations with (US, $40 \mathrm{kHz}, 37.5 \mathrm{~W} / \mathrm{dm}^{3}$ ) and without (CONTROL) ultrasound application. Average \pm standard deviations are shown. Subscripts $(a, b, c, d)$ show homogeneous group established from LSD intervals $(\mathrm{p}<0.05)$. 
17

18

Table 1

\begin{tabular}{cccccc}
\hline $\begin{array}{c}\text { NaCl concentration } \\
\left(\mathrm{kg} / \mathrm{m}^{3}\right)\end{array}$ & $\mathrm{D}_{\mathrm{s}}\left(10^{-10} \mathrm{~m}^{2} / \mathrm{s}\right)$ & $\%$ VAR & $\mathrm{D}_{\mathrm{s}}\left(10^{-10} \mathrm{~m}^{2} / \mathrm{s}\right)$ & $\%$ VAR & $(\%)$ \\
\hline 50 & 1.24 & 98.1 & 1.73 & 97.5 & 40 \\
100 & 2.04 & 99.2 & 2.93 & 96.6 & 44 \\
150 & 2.11 & 99.0 & 2.60 & 98.9 & 23 \\
200 & 1.99 & 96.4 & 2.68 & 95.1 & 35 \\
240 & 1.73 & 96.1 & 2.51 & 93.8 & 45 \\
280 & 1.96 & 96.1 & 2.62 & 99.5 & 34 \\
\hline
\end{tabular}

19

20

Table 2

\begin{tabular}{cccccc}
\hline $\begin{array}{c}\mathrm{NaCl} \text { concentration } \\
\left(\mathrm{kg} / \mathrm{m}^{3}\right)\end{array}$ & $\mathrm{D}_{\mathrm{W}}\left(10^{-10} \mathrm{~m}^{2} / \mathrm{s}\right)$ & \% VAR & $\mathrm{D}_{\mathrm{W}}\left(10^{-10} \mathrm{~m}^{2} / \mathrm{s}\right)$ & $\%$ VAR & $(\%)$ \\
\hline 50 & 0.76 & 90.7 & 1.92 & 91.6 & 153 \\
100 & 0.62 & 90.2 & 1.09 & 94.7 & 76 \\
150 & 0.17 & 89.1 & 0.24 & 92.2 & 41 \\
200 & - & - & - & - & - \\
240 & 1.04 & 81.1 & 2.60 & 88.8 & 150 \\
280 & 1.83 & 90.0 & 3.67 & 95.6 & 101 \\
\hline
\end{tabular}

22

Table 3

\begin{tabular}{cccc}
\hline & \multicolumn{3}{c}{$\mathrm{NaCl}$ concentration $\left(\mathrm{kg} / \mathrm{m}^{3}\right)$} \\
\cline { 2 - 4 } & 50 & 200 & 280 \\
\hline CONTROL & $1.27 \pm 0.39_{\mathrm{a}}$ & $1.78 \pm 0.60_{\mathrm{b}, \mathrm{c}}$ & $1.69 \pm 0.70_{\mathrm{b}, \mathrm{c}}$ \\
US & $1.65 \pm 0.52_{\mathrm{b}, \mathrm{c}}$ & $1.94 \pm 0.46_{\mathrm{b}, \mathrm{c}, \mathrm{d}}$ & $2.08 \pm 0.66_{\mathrm{d}}$ \\
\hline
\end{tabular}

23 
1 Influence of High Intensity Ultrasound Application on Mass Transport,

2 Microstructure and Textural Properties of Pork Meat (Longissimus dorsi)

\section{Brined at Different $\mathrm{NaCl}$ Concentrations.}

*Corresponding author.

Juan A. Cárcel.

Grupo de Análisis y Simulación de Procesos Agroalimentarios. Departamento de Tecnología de Alimentos. Universitat Politècnica de València.

Camino de Vera. s/n. E46022. Valencia, Spain

Tel.: +349638793 65; Fax: +34963879839

E-mail address: jcarcel@ tal.upv.es.

\section{Cárcel $^{\mathrm{a}, *}$}

${ }^{a}$ Grupo de Análisis y Simulación de Procesos Agroalimentarios. Departamento de Tecnología de Alimentos. Universitat Politècnica de València.

Camino de Vera. s/n. E46022. Valencia, Spain

Alimentos. Universitat Politècnica de València.

Camino de Vera. s/n. E46022. Valencia, Spain 


\section{ABSTRACT}

The aim of this work was to evaluate the effect of high intensity ultrasound and $\mathrm{NaCl}$ concentration on the brining kinetics $\left(5 \pm 1{ }^{\circ} \mathrm{C}\right)$ of pork loin as well as its influence on the textural and microstructural changes. In order to identify the effect of both factors on $\mathrm{NaCl}$ and moisture transport, kinetics were analyzed by taking the diffusion theory into account. The textural and microstructural analysis of raw and brined meat both with and without ultrasound application was carried out. The experimental results showed that the brine $\mathrm{NaCl}$ concentration not only determined the final $\mathrm{NaCl}$ content in meat samples but also the direction of water transport. The $\mathrm{NaCl}$ and moisture effective diffusivities were improved by ultrasound application. The final $\mathrm{NaCl}$ and moisture content and the ultrasound application promoted changes in instrumentally measured meat texture, which were confirmed via microstructural observations.

Keywords: mass transfer, power ultrasound, modeling, diffusivity, texture, Cryo-SEM, SEM. 


\section{Introduction}

Over 1.2 million tons of meat products produced per year makes Spain the fourth most important country in the European Union in this regard, being the dry-cured products the most valuable ones in the Spanish meat industry (AICE, 2011). One of the main stages during the processing of dry-cured products is salting. Actually, this operation is mainly carried out by salting the meat pieces with solid salts $(\mathrm{NaCl})$, but it could also be performed by brining (Barat et al., 2006). Compared with other food processes, brining is a slow process and, for that reason, the food industry is searching for alternative technologies for improving the mass transfer kinetics (Rastogi et al., 2002), such as high intensity ultrasound application (Cárcel et al., 2007a).

In liquid medium, ultrasound induces cavitation (Leighton, 1998), temperature gradients within the material (Mason and Lorimer, 2002), mechanical phenomena, such as the "sponge effect", generation of microchannels and microstirring on interfaces (Muralidhara et al., 1985). These effects can not only increase the mass transport kinetics but also imply structural changes and, consequently, changes in textural properties. Thereby, textural changes induced by ultrasound have been observed in, among others, tomato juice (Vercet et al., 2002), yoghurt (Wu et al., 2000), bell peppers (Gabaldón-Leyva et al. 2007) or meat (Jayasooriya et al., 2007; Pohlman et al., 1997).

Meat has great biochemical and structural complexity. During meat brining, changes in $\mathrm{NaCl}$ and moisture content take place (Graiver et al., 2006), which extend meat's shelf life and modify organoleptic characteristics, such as juiciness, texture and flavor. Mass transfer driving forces between meat and brine are linked to chemical gradients and $\mathrm{NaCl}$-induced changes in the water holding capacity (WHC) of meat proteins (Shi and Le Maguer, 2002; Vestergaard et al., 2005). The $\mathrm{NaCl}$ concentration in brine affects the direction of moisture transport as well as the equilibrium state (Cheng and Sun, 2008). A low NaCl content in the 
meat increases the water holding capacity (WHC) (Nguyen et al., 2010), a phenomenon known as "salting-in" which is linked to the meat protein net charge modification. However, a high $\mathrm{NaCl}$ content in meat could also bring about a decrease in WHC, probably due to the insolubilization of proteins ("salting-out") (Graiver et al., 2009). Therefore, the $\mathrm{NaCl}$ concentration in the brine solution can not only affect the chemical gradients, but also the WHC, thus affecting the magnitude of mass transport.

Modeling is a fundamental tool to quantify the mass transport (Cárcel et al., 2007a), as well as to evaluate the effectiveness on that of new technologies, such as ultrasound. But in addition, modeling also provides relevant information to understand the changes undergone by foodstuffs during processing, which usefulness complements the information given by other techniques, such as textural and microstructural ones (Pérez-Munuera et al., 2008). Thereby, different electron microscopy techniques, Larrea et al. (2007) have been used to characterize the microstructure of Biceps femoris and Semimebranousus muscles during the processing of Teruel dry-cured ham. Ruiz-Ramírez et al. (2005) described the effect of $\mathrm{NaCl}$ and $\mathrm{pH}$ on the relationship between water content and textural parameters in dry-cured muscles.

The main aim of this work was to evaluate the influence of high intensity ultrasound application on the meat brining kinetics using different $\mathrm{NaCl}$ concentrations in the brine solution. Moreover, the ultrasonic effects in transport phenomena have been quantified by modeling and linked to the induced changes in microstructural and textural meat properties.

\section{Materials and methods}

\subsection{Raw material and sample preparation}

Fresh pork loins (Longissimus dorsi) were purchased at a local slaughterhouse (Valencia, Spain). The pieces selected had a pH of $5.3 \pm 0.30$, which was measured in-situ by means of a pH-meter (pH STAR, Matthäus, Germany) at three different points along the muscle avoiding 
fatty areas. Parallelepiped shaped samples (length $50 \mathrm{x}$ width $30 \mathrm{x}$ thickness $10 \mathrm{~mm}$ ) were obtained from the central part of loin pieces using a sharp knife. Before brining, samples were wrapped in plastic waterproof film and kept frozen at $-18 \pm 0.5{ }^{\circ} \mathrm{C}$ (maximum storage time 120 hours).

\subsection{Brining treatments}

Brining experiments with (US, $40 \mathrm{kHz} ; 37.5 \mathrm{~W} / \mathrm{dm}^{3}$ ) and without ultrasound application (CONTROL) were carried out using brine solutions of different $\mathrm{NaCl}$ concentrations $(50,100$, 150, 200, 240 and $\left.280 \mathrm{~kg} \mathrm{NaCl} / \mathrm{m}^{3}\right)$. The highest $\mathrm{NaCl}$ concentration used $\left(280 \mathrm{~kg} / \mathrm{m}^{3}\right)$ involved brine saturation at $5 \pm 1{ }^{\circ} \mathrm{C}$, which was pointed to by the presence of $\mathrm{NaCl}$ crystals in the solution.

Brining treatments were carried out in an ultrasonic cleaning bath $(4 \mathrm{~L}, 40 \mathrm{kHz} ; 150 \mathrm{~W}$, Selecta, Spain) where the temperature was held at $5 \pm 1{ }^{\circ} \mathrm{C}$ by brine recirculation from a cooling reservoir. A peristaltic pump (302S Limited, Watson/Marlow, United Kingdom) drove the brine from the cooling reservoir equipped with a chiller (3000778, J.P. Selecta, Spain) and a mechanical stirrer (RZR 1, Heidolph Instruments, Germany).

Before each brining experiment, 6 meat samples were thawed at constant temperature $(2 \pm 1$ ${ }^{\circ} \mathrm{C}$ ) for $24 \mathrm{~h}$. Then, the samples were blotted, weighed (PB3002-S/PH, J.P., Mettler Toledo, Spain) and their size was measured by using a Vernier caliper. Afterwards, they were placed in a hollow sample holder and simultaneously introduced in the brine. For a homogenous brining, the position of the meat samples was changed every $5 \mathrm{~min}$. Samples were taken out of the brine at preset times $(15,30,45,60,90$ and 120 minutes) and immersed in distilled water for $20 \mathrm{~s}$ to remove any adhered surface brine. Finally, samples were blotted, wrapped in plastic waterproof film and frozen $\left(-18 \pm 0.5^{\circ} \mathrm{C}\right)$ until moisture and $\mathrm{NaCl}$ measurements were taken. 
122 at least.

$\mathrm{S}=\mathrm{S}_{\mathrm{eq}}+\left(\mathrm{S}_{0}-\mathrm{S}_{\mathrm{eq}}\right)\left[2 \sum_{\mathrm{n}=0}^{\infty} \frac{1}{\lambda_{\mathrm{n}}^{2} \mathrm{~L}^{2}} \mathrm{e}^{-\mathrm{D}_{\mathrm{S}} \lambda_{\mathrm{n}}^{2} \mathrm{t}}\right]$

where, $\lambda_{\mathrm{n}} \mathrm{L}=(2 \mathrm{n}+1) \frac{\pi}{2}$

$$
\text { where, } \lambda_{\mathrm{n}} \mathrm{L}=(2 \mathrm{n}+1) \frac{\pi}{2}
$$

138 Where the equilibrium moisture and $\mathrm{NaCl}$ content values $\left(S_{e}, W_{e}\right)$ were determined by 
141 Both effective diffusivity values, $D_{\mathrm{s}}$ and $\mathrm{D}_{\mathrm{w}}$, were identified by separately fitting Eqs. 1 and 2

142 to moisture and $\mathrm{NaCl}$ transport kinetics. The identification was performed by minimizing the 143 squared differences between the experimental and calculated average sample moisture and $144 \mathrm{NaCl}$ content. For that purpose, the Generalized Reduced Gradient (GRG) optimization 145 method, available in the Microsoft Excel spreadsheet from Microsoft Office XP Professional, 146 was used.

2.4.Textural and microstructural analysis

Meat texture and microstructure were studied in US and CONTROL brined samples for 120

150

minutes using low, intermediate and high $\mathrm{NaCl}$ concentrations $\left(50,200\right.$ and $280 \mathrm{~kg} \mathrm{NaCl} / \mathrm{m}^{3}$, respectively). Samples were brined in triplicate at least.

\subsubsection{Texture}

Hardness, characterized as maximum penetration force, was evaluated in brined samples using a Texture Analyzer (TAX-T2 ${ }^{\circledR}$, Stable Micro System, United Kingdom). Penetration tests were conducted with a $2 \mathrm{~mm}$ flat cylinder probe (SMS P/2N), a crosshead speed of 1 $\mathrm{mm} / \mathrm{s}$ and a strain of $60 \%$ (penetration distance $6 \mathrm{~mm}$ ). In each meat slice, penetration tests were carried out at 12 points at least.

\subsubsection{Cryo-scanning electron microscopy (Cryo-SEM)}

Cubic samples (side $3 \mathrm{~mm}$ ) of raw and brined meat were immersed in slush Nitrogen $(-210$ ${ }^{\circ} \mathrm{C}$ ), and quickly transferred to a cryo-trans (CT $15000 \mathrm{C}$, Oxford Instruments, England) linked to a scanning electron microscope (JSM-5410, Jeol, Japan). Samples were cryofractured at $-180{ }^{\circ} \mathrm{C}$, etched at $-90^{\circ} \mathrm{C}$ and gold-coated, allowing cross-section visualization. 
The microscopic observations were carried out at $10 \mathrm{kV}$, a working distance of $15 \mathrm{~mm}$ and a temperature below $-130{ }^{\circ} \mathrm{C}$.

2.4.3. Scanning electron microscopy (SEM) with combined dispersion X-ray analysis (SEM-EDX).

Cubic samples (side $3 \mathrm{~mm}$ ) from raw and brined meat were immersed in liquid $\mathrm{N}_{2}$ and then freeze-dried at $1 \mathrm{~Pa}$ for 3 days (LIOALFA-6, Telstar, Spain). The fixed samples were vacuum sealed in vials in the same freeze-drier so that they would remain stable (Llorca et al., 2001). The fixed samples were individually placed on SEM slides with the aid of colloidal silver and then gold-coated with (SCD005, Baltec, Germany) at $10^{-2} \mathrm{~Pa}$ and an ionization current of 40 mA. The samples were observed in a scanning electron microscope (JSM-5410, Jeol, Japan) equipped with an X-ray detector and LINK data-processing system (INCA 4.09, Oxford Instruments, England) at an acceleration voltage of $10-20 \mathrm{kV}$ which provides internal information about the standards of energy dispersive X-ray spectra of the elements analyzed $\left(\mathrm{Na}^{+}\right.$and $\left.\mathrm{Cl}^{-}\right)$. This technique is an analytical tool that allows the ions $\mathrm{Cl}^{-}$and $\mathrm{Na}^{+}$inside the samples to be identified (Grote and George, 1984). For EDX (energy-dispersive X-ray) analysis, samples were carbon-coated (CEA035, Baltec, Germany). Mapping images of $\mathrm{Cl}^{-}$ and $\mathrm{Na}^{+}$distribution in meat samples were made using a voltage of $20 \mathrm{kV}$ and at a working distance of $15 \mathrm{~mm}$.

\subsection{Fitting model evaluation and statistical analysis}

In order to evaluate the ability of the models to fit the experimental data, the percentage of explained variance (\%VAR) was computed (Eq. 3) (Cárcel et al., 2007a).

$\%$ VAR $=\left[1-\frac{S_{\mathrm{tw}}^{2}}{S_{\mathrm{w}}^{2}}\right] \times 100$ 
189 Where $\mathrm{S}^{2}{ }_{\mathrm{w}}$ and $\mathrm{S}_{\mathrm{tw}}^{2}$ are the variance of the sample and the estimation, respectively.

Multifactor ANOVA and LSD (Least Significant Difference) intervals were estimated to perform a statistical evaluation of the influence of ultrasound application and $\mathrm{NaCl}$ concentration on the effective diffusivity and textural properties. The statistical analysis was carried out using the Statgraphics Centurion XVI software package (Statistical Graphics Corp., Herdorn, USA).

\section{Results and discussion}

3.1. $\mathrm{NaCl}$ and water transport

\subsection{1. $\mathrm{NaCl}$ and water content}

Fig. 1 shows the $\mathrm{NaCl}$ content of loin samples during brining, which is also considered the $\mathrm{NaCl}$ gain, due to the fact that the $\mathrm{NaCl}$ content in meat samples was negligible. $\mathrm{NaCl}$ concentration in the brine influenced significantly on $\mathrm{NaCl}$ content (Fig. 2A). Thus, when using a brine solution of $50 \mathrm{~kg} \mathrm{NaCl} / \mathrm{m}^{3}$, the $\mathrm{NaCl}$ content in the meat (brining time $120 \mathrm{~min}$ ) was almost four times lower than when using $280 \mathrm{~kg} \mathrm{NaCl} / \mathrm{m}^{3}$. The $\mathrm{NaCl}$ gain is mainly linked to osmotic mechanisms, thus the hydrodynamic flux increases as the pressure gradients between the meat and brine get higher (Schmidt et al., 2008). Other factors, such as temperature, $\mathrm{pH}$ and muscle microstructure, can also affect the $\mathrm{NaCl}$ gain (Barat et al., 2006).

Ultrasound also significantly ( $\mathrm{p}<0.05$ ) influenced the $\mathrm{NaCl}$ gain (Fig. $2 \mathrm{~B}$ ); as an example, for a brining time of $90 \mathrm{~min}$ and using the highest $\mathrm{NaCl}$ concentration $\left(280 \mathrm{~kg} \mathrm{NaCl} / \mathrm{m}^{3}\right)$, the $\mathrm{NaCl}$ content in the CONTROL samples was $0.315 \pm 0.020 \mathrm{~kg} \mathrm{NaCl} / \mathrm{kg}$ initial d.m. while the content in US samples reached $0.359 \pm 0.033 \mathrm{~kg} \mathrm{NaCl} / \mathrm{kg}$ initial d.m. (Fig. 1). Among other phenomena, the US application in liquid media induces cavitation, temperature gradients within the material, alternative compression and decompression of the material, the generation of microchannels and microstirring on interfaces, which are responsible for the 
increased gain in NaCl. Cárcel et al. (2007a) and Gabaldón-Leyva et al. (2007) also found significant differences $(\mathrm{p}<0.05)$ in the net increase of dry matter content during the ultrasound assisted osmotic treatment of apple and red bell pepper.

Regarding the moisture content, pork loin showed average initial moisture content of $3.10 \pm 0.12 \mathrm{~kg}$ water $/ \mathrm{kg}$ initial d.m. As can be observed in Fig. 3, the concentration of $\mathrm{NaCl}$ in the brine solution is a key parameter in moisture transport, since it determines the direction of water flux. The ANOVA carried out with samples brined for 120 min reflected that samples could be classified in three significantly different groups according to the moisture content (Fig. 2 C). The first group included samples brined using 50 and $100 \mathrm{~kg} \mathrm{NaCl} / \mathrm{m}^{3}$, which showed a significant $(\mathrm{p}<0.05)$ water gain. Samples brined using 150 and $200 \mathrm{~kg} \mathrm{NaCl} / \mathrm{m}^{3}$ (the second group) neither lost nor gained water, having similar moisture content to raw meat. This result coincided with what was reported by Graiver et al. (2009) and Nguyen et al. (2010), who did not find a clear moisture transport when using brines close to $200 \mathrm{~kg}$ $\mathrm{NaCl} / \mathrm{m}^{3}$, either. Finally, the third group included samples brined at 240 and $280 \mathrm{~kg} \mathrm{NaCl} / \mathrm{m}^{3}$, which underwent dehydration. During brining however, hydration or dehydration are not only affected by chemical potential gradient (Shi and Le Maguer, 2002) but also by structural changes brought about in the meat by salt gain (Schmidt et al., 2008). On the one side, the low $\mathrm{NaCl}$ content increases the muscle's WHC by protein solubilization, which is known, as aforementioned, the "salting-in" phenomenon (Offer and Trinick, 1983). On the other side, the high $\mathrm{NaCl}$ content reduces the WHC and meat muscle shrinks, which is the "salting-out" phenomenon (Graiver et al., 2006).

Regarding ultrasound effect on transport kinetics, the moisture content of US and CONTROL samples brined for 120 min was not significantly $(\mathrm{p}<0.5)$ different. (Fig. 2 D). This fact has been also been observed in ultrasound assisted brining of beef muscles (Pohlman et al., 1997; Jayasooriya et al. 2007) and pork meat (Siró et al. 2009). The negligible effect of ultrasound 
on water content could be linked to the great variability in moisture content of samples (Fig. 3) if it is compared to the $\mathrm{NaCl}$ content (Fig. 1). In addition, it should be considered that the ultrasound intensity may be not enough to provoke significant differences in water transport due to a minim amount of ultrasonic energy is necessary in the medium, and that threshold could be different for water and $\mathrm{NaCl}$ content. Cárcel et al., (2007 b) reported that in high intensity ultrasound fields, brine could be microinjected into the meat leading to a direct increase of $\mathrm{NaCl}$ and water content.

\subsection{Modeling transport kinetics}

The analysis of the experimental results has been focused on the final salt and moisture content (samples brined for $120 \mathrm{~min}$ ). Modeling the experimental transport kinetics (Figs. 1 and 3) will help to identify whether the brining conditions (US application and/or $\mathrm{NaCl}$ concentration) affect the process rate. The fit of the models to experimental kinetics achieved percentages of explained variance (Table 1) ranging from 93 to $99 \%$ for $\mathrm{NaCl}$ transport, being the figures slightly lower for moisture transport (81.1 to $95.6 \%$ ), which could indicate a poor fit in this case. However, as can be observed in Fig. 4, there exists a similar trend between calculated and experimental moisture contents in both cases, which highlights how suitable the proposed diffusion model is to describe the brining process. The low explained variance provided by the diffusion model in the moisture transport should mostly linked to the great variability of the initial composition of raw meat. Therefore, diffusion could be considered the predominant mass transport mechanism during brining.

The $\mathrm{D}_{\mathrm{s}}$ values were similar for all the different brine concentrations tested; a lower figure was only found for all $\mathrm{NaCl}$ concentration of $50 \mathrm{~kg} \mathrm{NaCl} / \mathrm{m}^{3}$, probably due to the structural changes in meat samples brought about by low salt gain. The effective $\mathrm{NaCl}$ diffusivities identified for the CONTROL samples agree closely with the values reported in the literature 
264 (Graiver et al., 2006; Vestergaard et al., 2007), which actually range between $2-4 \times 10^{-10} \mathrm{~m}^{2} / \mathrm{s}$.

265 Regarding moisture transport, the $D_{w}$ values identified in experiments where meat was 266 hydrated $\left(\mathrm{NaCl}\right.$ concentration lower than $\left.200 \mathrm{~kg} / \mathrm{m}^{3}\right)$ decreased as the $\mathrm{NaCl}$ content rose. 267 Thus, in CONTROL experiments using a brining solution of $50 \mathrm{~kg} \mathrm{NaCl} / \mathrm{m}^{3}$, the $\mathrm{D}_{\mathrm{w}}$ was $2680.76 \times 10^{-10} \mathrm{~m}^{2} / \mathrm{s}$, while $D_{\mathrm{w}}$ decreased to $0.17 \times 10^{-10} \mathrm{~m}^{2} / \mathrm{s}$ for experiments at $150 \mathrm{~kg} / \mathrm{m}^{3}$, where 269 hydration was almost negligible. The same fact was also observed in US experiments and has also been previously reported by Gou et al., (2003), who found that the $\mathrm{D}_{\mathrm{w}}$ decreased when 271 the $\mathrm{NaCl}$ content of the salting solutions increased from 20 to $80 \mathrm{~kg} \mathrm{NaCl} / \mathrm{m}^{3}$. On the other

272 hand, the $\mathrm{D}_{\mathrm{w}}$ values were higher when meat was dehydrated $(\mathrm{NaCl}$ concentration higher than $\left.200 \mathrm{~kg} \mathrm{NaCl} / \mathrm{m}^{3}\right)$ than when meat was hydrated $(\mathrm{NaCl}$ concentration lower than $200 \mathrm{~kg}$ $\mathrm{NaCl} / \mathrm{m}^{3}$ ) (Table 2). These differences could be ascribed to the different product structure induced and controlled by $\mathrm{NaCl}$ transport (Schmidt et al., 2008; Gou et al., 2003; Offer and Trinick, 1983). Therefore, the $\mathrm{NaCl}$ concentration in the brining solution is not only affecting the direction of water flux (hydration or dehydration) but also the water transport rate as a consequence of the structural changes brought about by the $\mathrm{NaCl}$ content in the meat.

Ultrasound application led to a significant $(\mathrm{p}<0.05)$ improvement in both $\mathrm{D}_{\mathrm{s}}$ and $\mathrm{D}_{\mathrm{w}}$, which points to an acceleration of both the global bring process. The increase in $\mathrm{D}_{\mathrm{s}}$ ranged from 23 to $45 \%$ and is in a similar range to other improvements reported for solid transport in the literature. Thus, Siró et al. (2009) found increases of 96\% in $\mathrm{D}_{\mathrm{s}}$ meat brining and GabaldónLeyva et al. (2007) stated an improvement of $190 \%$ in the total solid diffusion coefficients. In the case of $\mathrm{D}_{\mathrm{w}}$, the improvement was higher than in $\mathrm{D}_{\mathrm{s}}$ for the lowest and highest $\mathrm{NaCl}$ concentrations used $\left(50\right.$ and $\left.280 \mathrm{~kg} / \mathrm{m}^{3}\right)$ (Table 1), being in this case the improvement close to 100\%. Gabaldón-Leyva et al., 2007 and Cárcel et al., 2007a reported increases in $\mathrm{D}_{\mathrm{w}}$ of around 128 and $117 \%$ when ultrasound was applied in bell pepper brining and osmotic dehydration of apple. Smaller increases were observed in the $\mathrm{D}_{\mathrm{w}}$ values for intermediate $\mathrm{NaCl}$ 
concentration brines tested, these being $76 \%$ and $41 \%$ for 100 and $150 \mathrm{~kg} / \mathrm{m}^{3}$, respectively. The different effectiveness of ultrasound application depending on brine $\mathrm{NaCl}$ concentration could be explained considering that the ultrasound effects on mass transport are largely dependent on product structure (Gabaldón-Leyva et al., 2007). Finally, it should be remarked that there was not a significant $(\mathrm{p}<0.05)$ difference on the moisture content at the end of the brining process (120 min) for CONTROL and US samples, however, the analysis of transport kinetics showed an improvement on the moisture transport rate by ultrasound, which resulted no significant at the end of the brining process.

The effective moisture diffusivities identified from experimental results are kinetic parameters that not only include diffusion mechanisms but also other existing phenomena not considered in the model, such as external mass transport. Ultrasound may affect both internal mass transport resistance, by alternating cycles of expansions and contractions ("sponge effect") and the generation of microchannels, and external by microstirring at the interfaces (Muralidhara et al., 1985, Cárcel et al., 2007b). These effects that US induce into the medium are responsible for the kinetic improvement.

\subsection{Texture}

In order to study the influence of ultrasound application and $\mathrm{NaCl}$ concentration on meat texture, instrumental penetration tests were carried out in US and CONTROL samples brined for 120 min using $\mathrm{NaCl}$ concentrations of 50,200 and $280 \mathrm{~kg} / \mathrm{m}^{3}$. At least 12 points were measured in each meat slice.

CONTROL samples brined at 200 and $280 \mathrm{~kg} \mathrm{NaCl} / \mathrm{m}^{3}$ were significantly $(\mathrm{p}<0.05)$ harder than those brined at $50 \mathrm{~kg} \mathrm{NaCl} / \mathrm{m}^{3}$ (Table 3). As aforementioned, the higher the $\mathrm{NaCl}$ concentration in the brine, the greater the $\mathrm{NaCl}$ gain. In such a way, the $\mathrm{NaCl}$ gain promoted changes in meat texture, leading to harder samples, a fact already showed by Ruiz-Ramírez et 
al. (2005). Non-significant differences $(p<0.05)$ in hardness were found in samples brined at 200 and $280 \mathrm{~kg} \mathrm{NaCl} / \mathrm{m}^{3}$ (Table 3). This indicates that the level of $\mathrm{NaCl}$ gained by both samples was enough to produce the same change in meat texture. The effect of the $\mathrm{NaCl}$ concentration in US samples was similar to that reported in CONTROL ones.

On the other hand, the application of ultrasound during brining significantly increased $(\mathrm{p}<0.05)$ the meat hardness. As already explained, ultrasound application intensified $\mathrm{NaCl}$ transport during brining, increasing not only the $\mathrm{NaCl}$ diffusivity but also the final $\mathrm{NaCl}$ content (brining time, $120 \mathrm{~min}$, CONTROL $0.326 \pm 0.007 \mathrm{~kg} \mathrm{NaCl} / \mathrm{kg}$ initial d.m. and US 0.409.29 $\pm 0.11 \mathrm{~kg} \mathrm{NaCl} / \mathrm{kg}$ initial d.m.). So, the effects of ultrasound on meat texture could be linked to the intensification of $\mathrm{NaCl}$ transport, which provoked structural changes in meat proteins. Lee and Feng (2011) reported that the texture of ultrasound-treated food is influenced by protein changes during sonication, as well as Siró et al., (2009), who linked the hardening of meat tissue to the high ultrasonic intensities applied. Sanchez et al., (2001) showed that US application in the brining of Mahon cheese increased the sample hardness due to the improvement of proteolysis and lipolysis reactions.

Raw and brined CONTROL and US pork loin previously characterized from instrumental texture were studied by Cryo-SEM and SEM techniques in order to contribute to a better understanding of the effects produced by ultrasound application, being this fact analyzed in the following section.

\subsection{Microstructure}

3.4.1. Cryo-scanning electron microscopy (Cryo-SEM)

First of all the microstructure of raw pork loin was characterized. Fig. 5A shows a cross section of the raw pork loin, where cells are surrounded by the membrane or sarcolemma (Fig. 5A, S). These cells are interconnected by endomysial connective tissue (Fig. 5A, EC), 
which keeps the muscle fibers tightly attached. In addition, the myofibrils inside the muscle cell can be observed, which are fundamental components of the cell's contractile apparatus (Fig. 5A, M).

Intercellular spaces appear full of typical eutectic artifacts in brined samples (Figs. 5B, C and D) due to solute aggregation after water sublimation provoked by Cryo-SEM technique (Pérez-Munuera et al., 2008). The accumulation of solutes in the intercellular spaces can be linked to both the penetration of the $\mathrm{NaCl}$ and the strong solubilization and dehydration in muscle tissue. The greater the brining $\mathrm{NaCl}$ concentration, the greater the solute accumulation and the more compact the eutectic artifacts (Larrea et al., 2007). The bundles of muscle fibers in CONTROL samples brined at $280 \mathrm{~kg} / \mathrm{m}^{3}$ (Fig. 5D) seem to be more compact, showing the more intense sample dehydration linked to the "salting-out" phenomenon. The denaturation and precipitation of proteins involves progressive structural shrinkage and less space for water (Vestergaard et al., 2005). These effects are widely related with the hardening observed in the textural analysis of meat brined at the highest $\mathrm{NaCl}$ concentration $\left(280 \mathrm{~kg} \mathrm{NaCl} / \mathrm{m}^{3}\right)($ Table 3). In samples brined at the lowest $\mathrm{NaCl}$ concentration $\left(50 \mathrm{~kg} \mathrm{NaCl} / \mathrm{m}^{3}\right.$, Fig. $\left.5 \mathrm{~B}\right)$, however, may be observed an expansion of myofibrils coupled with the protein solubilization that is related with the "salting-in" phenomena (Graiver et al., 2006). Some authors have already reported that an increase in water binding and hydration in the muscle fibers of brined meat at low brine concentrations $\left(<50 \mathrm{~kg} \mathrm{NaCl} / \mathrm{m}^{3}\right)$ is ascribed to enhanced electrostatic repulsion between myofibril filaments causing the filament lattice to expand for water entrapment (Graiver et al., 2009; Cheng and Sun, 2008). These phenomena in meat proteins can explain the hydration of samples brined at low $\mathrm{NaCl}$ concentrations (Fig. 3) and the meat softening observed in the textural analysis (Table 3).

Samples brined with $200 \mathrm{~kg} \mathrm{NaCl} / \mathrm{m}^{3}$ (Fig. 5C), showed a mixed effect. Some parts of the sample show structural dehydration due to a high $\mathrm{NaCl}$ concentration (Fig. 5C, 1), whereas in 
other parts of the sample, the opposite phenomena (hydration) can be observed in the myofibrillar structure (Fig. 5C, 2). As mentioned before (Fig. 3), no net transport of moisture was identified at $200 \mathrm{~kg} \mathrm{NaCl} / \mathrm{m}^{3}$, which can be linked to the combined effect of hydrationdehydration observed in the meat microstructure (Fig. 5C).

From micrographs obtained with Cryo-SEM, no effects of ultrasound in the meat structure were found. Thus, the Cryo-SEM microstructural analysis was completed with SEM observations.

\subsubsection{Scanning electron microscopy (SEM) with combined dispersion X-ray analysis} (SEM-EDX).

CONTROL samples brined with the lowest $\mathrm{NaCl}$ concentration tested $\left(50 \mathrm{~kg} \mathrm{NaCl} / \mathrm{m}^{3}\right.$, Fig. 6B) showed a swelling of muscle fibers (width $87.6 \pm 7.3 \mu \mathrm{m}$ ) compared to raw meat (width $72.5 \pm 9.1 \mu \mathrm{m})$ (Fig. 6A). The swelling of muscle fibers could be mainly ascribed to the "salting-in" phenomena. Samples brined at higher $\mathrm{NaCl}$ concentrations behaved in the opposite way and presented a dehydration of muscle fibers and an accumulation of $\mathrm{NaCl}$; these effects may be observed in Figs. 7A, C, E.

The SEM technique also allowed the effect brought about by high intensity ultrasound in meat structure to be observed, this effect mainly focusing on myofibrils (Figs. 7B, D, F). The micrograph of the US sample brined at $50 \mathrm{~kg} \mathrm{NaCl} / \mathrm{m}^{3}$ (Fig. 7B) shows the disruption and the dispersion of the connective tissue of the fibers caused by US application. In Fig. 7F the rupture of a myofibril provoked by the acoustic energy was identified. The aforementioned myofibrillar changes could be explained by the alternating compressions and decompressions induced by US in solid materials ("sponge effect"). Another important effect produced by high intensity ultrasound in liquid media is cavitation, which may be observed in Fig. 7D, where the erosion of meat fiber produced by cavitation is shown. The asymmetric implosion 
of bubbles near the solid surface could produce violent microjets that collide with the samples, which can improve mass transfer by disturbing the boundary layer and producing changes in the meat structure. These results coincide with those found by several authors that related the application of high power ultrasound with the physical disruption of cellular and sub-cellular components (Reynolds et al., 1978), the degradation of collagen macromolecules (Nishira and Doty, 1958), and the creation of micro channels (Muralidhara et al., 1985).

The obtained SEM-EDX mapping images confirmed the presence of $\mathrm{NaCl}$ in meat after brining, which is shown up by the red $\left(\mathrm{Cl}^{-}\right)$and green $\left(\mathrm{Na}^{+}\right)$dots in the micrographs. As can be observed in Fig. 8, the $\mathrm{NaCl}$ concentration in US samples (Figs. 8B, C and D) was higher than those observed in CONTROL samples, as manifested by a higher number of dots in the micrographs (Figs. 8A, C and E). In CONTROL samples (Figs. 8A, C and E), $\mathrm{NaCl}$ molecules are mainly located around the myofibrils. However, the US brined samples (Figs. 8A, $\mathrm{C}$ and $\mathrm{E}$ ) showed a more homogeneous $\mathrm{NaCl}$ dispersion due to the collapse of myofibrillar structure caused by the effects of high power ultrasound, permitting a higher $\mathrm{NaCl}$ penetration in the meat. The obtained SEM-EDX images showed the intensification of $\mathrm{NaCl}$ transport brought about by US application and the increase in $\mathrm{NaCl}$ content, which confirms the results provided by modeling and textural tools.

\section{Conclusions}

The $\mathrm{NaCl}$ concentration in the brine solution significantly $(\mathrm{p}<0.05)$ affected moisture and $\mathrm{NaCl}$ transport during meat brining. At $\mathrm{NaCl}$ concentrations of under $200 \mathrm{~kg} / \mathrm{m}^{3}$, the meat was hydrated while, at concentrations of over $200 \mathrm{~kg} / \mathrm{m}^{3}$, it underwent dehydration. As for the $\mathrm{NaCl}$ transport, the more concentrated the brine, the greater the $\mathrm{NaCl}$ sample gain. Ultrasound application intensified the brining kinetics, increasing both moisture effective and $\mathrm{NaCl}$ diffusivities. The $\mathrm{NaCl}$ gain promoted changes in meat texture, high $\mathrm{NaCl}$ contents leading to 
414 harder samples. Microstructural analyses showed that the application of high intensity

415 ultrasound during brining brought about relevant effects on meat microstructure, such as a

416 more homogeneous $\mathrm{NaCl}$ distribution in meat. Therefore, ultrasound could be considered a

417 potential technology with which to accelerate the brining process.

418

419 Acknowledgments

420 This work is financed by project CARNISENUSA (CSD2007-00016) included in the 421 CONSOLIDER-INGENIO-2010.

422

\section{$423 \quad$ Nomenclature}

$\mathrm{W}_{\mathrm{eq}} \quad$ Equilibrium moisture content, $\mathrm{kg}$ water/kg initial d.m.

$\mathrm{W}_{0} \quad$ Initial moisture content, $\mathrm{kg}$ water/kg initial d.m.

$\mathrm{S}_{\mathrm{eq}} \quad$ Equilibrium sodium chloride content, $\mathrm{kg} \mathrm{NaCl} / \mathrm{kg}$ initial d.m.

$\mathrm{S}_{0} \quad$ Initial sodium chloride content, $\mathrm{kg} \mathrm{NaCl} / \mathrm{kg}$ initial d.m.

$\mathrm{D}_{\mathrm{S}} \quad$ Effective $\mathrm{NaCl}$ diffusivity $\left(\mathrm{m}^{2} / \mathrm{s}\right)$

$\mathrm{D}_{\mathrm{w}} \quad$ Effective moisture diffusivity $\left(\mathrm{m}^{2} / \mathrm{s}\right)$

L Half length, m 


\section{References}

Asociación de industrias de la carne de España (AICE), available online http://www.aice.es. Accesed on November 01, 2011.

Association of Official Analytical Chemists. Official Methods of Analysis; AOAC: Washington, DC, 1997.

Barat, J.M., Grau, R., Ibáñez, J.B., Pagán, M.J., Flores M., Toldrá F., \& Fito P. (2006). Accelerated processing of dry-cured ham. Part I. Viability of the use of brine thawing/salting operation. Meat Science, 72 (4), 757-765.

Cárcel, J.A., Benedito, J., Roselló, C., \& Mulet, A. (2007a). Influence of ultrasound intensity on mass transfer in apple immersed in a sucrose solution. Journal of Food Engineering, 78 (2), 472-479.

Cárcel, J.A., Benedito, J., Bon, J., \& Mulet A. (2007b). High intensity ultrasound effects on meat brining. Meat Science, 76 (4), 611-619.

Cheng, Q., \& Sun, D.-W. (2008). Factors affecting the water holding capacity of red meat products: a review of recent research advances. Critical Reviews in Food Science and Nutrition, 48 (2), 137-159.

Crank, J. (1975). The Mathematics of Diffusion. London: Oxford University Press.

Gabaldón-Leyva, C. A., Quintero-Ramos, A., Barnard, J., Balandrán-Quintana, R. R., Talamás-Abbud, R. T., \& Jiménez-Castro, J. (2007). Effect of ultrasound on the mass transfer and physical changes in brine bell pepper at different temperature. Journal of Food Engineering, 81(2), 374-379.

Gou, P., Comaposada, J., \& Arnau, J. (2003). NaCl content and temperature effects on moisture diffusivity in the Gluteus medius muscle of pork ham. Meat Science, 63 (1), 29-34. 
Graiver, N., Pinotti, A., Califano, A., \& Zaritzky, N. (2006). Diffusion of sodium chloride in pork tissue. Journal of Food Engineering, 77 (4), 910-918.

Graiver, N., Pinotti, A., Califano, A., \& Zaritzky, N. (2009). Mathematical modeling of the uptake of curing salts in pork meat. Journal of Food Engineering, 95 (4), 533-540.

Grote, M. \& Georg, H. (1984) Determination of element concentrations in fresh and processed vegetables by quantitative X-ray microanalysis. Food Microstructure, 3 (1), $49-54$.

Jayasooriya S.D., Torley P.J., D’Arcy B.R. \& Bhandari B.R. (2007). Effect of high power ultrasound and ageing on the physical properties of bovine Semitendinous and Longissimus muscles. Meat Science, 75 (4), 628-639.

Larrea, V., Pérez-Munuera, I., Hernardo, I., Quiles, A., Llorca, E., \& Lluch, M.A. (2007). Microstructural changes in Teruel dry-cured ham during processing. Meat Science, 76 (3), 574-582.

Lee, H. \& Feng, H. (2011). Effect of power ultrasound on food quality. In Feng, H., BarbosaCánovas, G.M. \& Weiss, J. (Eds.), Ultrasound Technologies for Food and Bioprocessing (pp. 559-582). London: Springer.

Leighton, T. G. (1998). The principles of cavitation. In M. J. W. Povey \& T. J. Mason (Eds.), Ultrasound in Food Processing (pp. 151-182). London: Chapman \& Hall.

Llorca, E., Puig, A., Hernando, I., Salvador, A., Fiszman S., \& Lluch, M.A. (2001). Effect of fermentation time on texture and microstructure of pickled carrots. Journal of the Science of Food and Agriculture, 81 (15), 1553-1560.

Mason, T. J., \& Lorimer, J. P. (2002). Applied sonochemistry. The uses of power ultrasound in chemistry and processing. Weinheim: Wiley-VCH.

Muralidhara, H. S., Ensminger, D., \& Putnam, A. (1985). Acoustic dewatering and drying (low and high frequency): State of the art review. Drying Technology, 3(4), 529-566. 
Nguyen, M.V., Arason, A., Thorarinsddottir, K.A., Thorkelsson, G. \& Gudmundsdóttir, A. (2010). Influence of salt concentration on the salting kinetics of cod loin (Gadus morhua) during brine salting. Journal of Food Engineering, 100 (2), 225-231.

Nishira, T., \& Doty, P. (1958). The sonic fragmentation of collagen macromolecules. Proceedings of the National Academy of Sciences of the United States of America, $44(5), 411-417$.

Offer, G. \& Trinick, J. (1983). On the mechanism of water holding in meat: The swelling and shrinking of myofibrils. Meat Science, 8 (4), 245-281.

Pérez-Munuera, I., Larrea, V., Quiles, A., \& Lluch, M.A. (2008). Microstructure of muscle foods. In L.M.L., Nollet \& F. Toldrá (Eds.), Handbook of muscle food analysis (pp. 335-352). Boca Raton FL: CRC Press Taylor \& Francis Group.

Pohlman, F.W, Dikeman M.E., \& Kropf D.H. (1997). Effects of high intensity ultrasound treatment, storage time and cooking method on shear, sensory, instrumental color and cooking properties of packaged and unpackaged beef pectoralis muscle, Meat Science, $46(1), 89-100$.

Rastogi, N.K., Raghavarao, K.S.M.S., Niranjan, K., \& Knorr, D. (2002). Recent developments in osmotic dehydration: methods to enhance mass transfer. Trends in Food Science \& Technology, 13 (2), 48-59.

Reynolds, J.B., Anderson D.B., Schmidt, G.R., Theno, D.M., \& Siegel D.G. (1978). Effects of ultrasonic treatment on binding strength in cured ham rolls. Journal of Food Science, 43 (3), 866-869.

Ruiz-Ramírez, J., Arnau, J., Serra, X., \& Gou, P. (2005). Relationship between water content, $\mathrm{NaCl}$ content, $\mathrm{pH}$ and texture parameters in dry-cured muscles. Meat Science, 70 (4), $579-587$. 
Sanchez, E. S., Simal, S., Femenía, A., Benedito, J. \& Roselló, C. (2001). Effect of acoustic brining on lipolysis and on sensory characteristics of Mahon cheese. Journal of Food Science, 66(6), 892-896.

Schmidt, F.C., Carciofi, B.A.M. \& Laurindo, J. B. (2008). Salting operational diagrams for chicken breast cuts: Hydration-dehydration. Journal of Food Engineering, 88 (1), 3644.

Shi J. \& Le Maguer M. (2002). Osmotic dehydration of foods: mass transfer and modelling aspects. Food Reviews International, 18(4), 305-335.

Siró, I., Vén, C., Balla, C., Jónás, G., Zeke, I., \& Friedrich, L. (2009). Application of an ultrasonic assisted curing technique for improving the diffusion of sodium chloride in porcine meat. Journal of Food Science, 91 (2), 363-362.

Vercet, A., Sánchez, C., Burgos, J., Montañés, L., \& Buesa, P. L. (2002). The effects of manothermosonication on tomato pectic enzymes and tomato paste rheological properties. Journal of Food Engineering, 53 (3), 273-278.

Vestergaard, C., Lohmann Andersen, B., \& Adler-Nissen, J. (2007). Sodium diffusion in cured pork determined by ${ }^{22} \mathrm{Na}$ radiology. Meat Science, 76 (2), 258-265.

Vestergaard, C., Risum, J., \& Adler-Nissen, J. (2005). ${ }^{23}$ Na-MRI quantification of sodium and water mobility in pork during brine curing. Meat Science, 69 (4), 663-672.

Wu, H., Hulbert, G. J., \& Mount, J. R. (2000). Effects of ultrasound on milk homogenization and fermentation with yogurt starter. Innovative Food Science and Emerging Technologies, 1 (13), 211-218. 